\title{
Acting, predicting and intervening in a socio-hydrological world
}

\author{
S. N. Lane \\ Institute of Earth Surface Dynamics, Faculté des géosciences et de l'environnement, Université de Lausanne, \\ Lausanne, Switzerland \\ Correspondence to: S. N. Lane (stuart.lane@unil.ch)
}

Received: 29 July 2013 - Published in Hydrol. Earth Syst. Sci. Discuss.: 16 August 2013

Revised: 15 January 2014 - Accepted: 26 January 2014 - Published: 7 March 2014

\begin{abstract}
This paper asks a simple question: if humans and their actions co-evolve with hydrological systems (Sivapalan et al., 2012), what is the role of hydrological scientists, who are also humans, within this system? To put it more directly, as traditionally there is a supposed separation of scientists and society, can we maintain this separation as sociohydrologists studying a socio-hydrological world? This paper argues that we cannot, using four linked sections. The first section draws directly upon the concern of sciencetechnology studies to make a case to the (socio-hydrological) community that we need to be sensitive to constructivist accounts of science in general and socio-hydrology in particular. I review three positions taken by such accounts and apply them to hydrological science, supported with specific examples: (a) the ways in which scientific activities frame socio-hydrological research, such that at least some of the knowledge that we obtain is constructed by precisely what we do; (b) the need to attend to how socio-hydrological knowledge is used in decision-making, as evidence suggests that hydrological knowledge does not flow simply from science into policy; and (c) the observation that those who do not normally label themselves as socio-hydrologists may actually have a profound knowledge of socio-hydrology. The second section provides an empirical basis for considering these three issues by detailing the history of the practice of roughness parameterisation, using parameters like Manning's $n$, in hydrological and hydraulic models for flood inundation mapping. This history sustains the third section that is a more general consideration of one type of sociohydrological practice: predictive modelling. I show that as part of a socio-hydrological analysis, hydrological prediction needs to be thought through much more carefully: not only because hydrological prediction exists to help inform decisions that are made about water management; but also
\end{abstract}

because those predictions contain assumptions, the predictions are only correct in so far as those assumptions hold, and for those assumptions to hold, the socio-hydrological system (i.e. the world) has to be shaped so as to include them. Here, I add to the "normal" view that ideally our models should represent the world around us, to argue that for our models (and hence our predictions) to be valid, we have to make the world look like our models. Decisions over how the world is modelled may transform the world as much as they represent the world. Thus, socio-hydrological modelling has to become a socially accountable process such that the world is transformed, through the implications of modelling, in a fair and just manner. This leads into the final section of the paper where I consider how socio-hydrological research may be made more socially accountable, in a way that is both sensitive to the constructivist critique (Sect. 1), but which retains the contribution that hydrologists might make to sociohydrological studies. This includes (1) working with conflict and controversy in hydrological science, rather than trying to eliminate them; (2) using hydrological events to avoid becoming locked into our own frames of explanation and prediction; (3) being empirical and experimental but in a sociohydrological sense; and (4) co-producing socio-hydrological predictions. I will show how this might be done through a project that specifically developed predictive models for making interventions in river catchments to increase high river flow attenuation. Therein, I found myself becoming detached from my normal disciplinary networks and attached to the co-production of a predictive hydrological model with communities normally excluded from the practice of hydrological science. 


\section{Introduction}

"No one sees the earth globally and no one sees an ecological system from nowhere, the scientist no more than the citizen, the farmer or the ecologist - or, lest we forget, the earthworm. Nature is no longer what is embraced from a far away point of view where the observer could ideally jump to see things "as a whole", but the assemblage of contradictory entities that have to be composed together." (B. Latour, 2011)

The thesis of this paper welcomes the potential of sociohydrology (after Sivapalan et al., 2012) as part of a new decade of hydrological activity concerned with prediction under change. However it argues that, if we live and work within landscapes where society and water have both coevolved and are intimately connected, how we predict water within those landscapes must also be considered as a sociohydrological problem.

To introduce my argument, I start with a quote from Sivapalan et al. (2011) concerned with the challenge of sociohydrology: "Explicitly confronting hydrological prediction with human behaviour poses challenges in the description and quantification of hydrological systems in terms that are meaningful in economic or policy frameworks ... Given the multiple scales, multiple decision-makers and multiple processes that drive the evolution of coupled human and water systems, they pose enormous challenges for prediction over long time scales." (p. 8, my emphasis in italic)

This quote is instrumental for this paper because it emphasises that hydrological science, and especially sociohydrological science, is a science that actively matters: whether through securing the safe supply of clean water, sustaining vital ecosystem services or defining strategies to avoid our exposure to extreme hydrological events, it is a science intimately bound with society and its needs. Yet it also emphasises that socio-hydrology is a science that is shaped by economic and/or policy frameworks. Such shaping arises for two reasons:

1. prediction of the future is not an open-ended process; rather it requires a series of important assumptions to be made about what should be included in the predictive model used, which elements are to be left stationary and which are to be left dynamic, etc. (Lane et al., 2011a), effectively a series of acts of framing by the scientists involved; and

2. because social futures are not well defined in a sociohydrological world, this framing is as much about statements about what the social could be, even should be. That is, whilst framing of futures may have a scientific basis (e.g. in future rainfall predictions), in a socio-hydrological world there will be many other elements to this framing over which a hydrological scientist cannot claim a particular privilege.

Socio-hydrology clearly represents an exciting opportunity, as it offers the potential for a series of innovative collaborations between hydrological scientists and social scientists to develop new ways of understanding sociohydrological systems and perhaps to develop new predictive approaches. There is also a debate to be had over precisely what the hydrological contribution might be to understanding in socio-hydrology, given that social scientists have been studying the co-evolution of social and hydrological systems for very many years (see the classic text by Wittfogel (1957), for example). This paper does not address this debate. Rather, it looks critically at the notion of socio-hydrology through a different perspective, that provided by science technology studies (STS), and in so doing, it argues, for hydrological scientists who might be interested in working in a socio-hydrological framework, that socio-hydrological practice will need much more than the "bolting on" of social science questions to hydrological science questions. It will require a wholesale rethink of how we practise hydrological science within a socio-hydrological project.

STS provide a theoretical framework for this rethinking. The last few decades have seen the development of what has been called a "sociological turn" in studies of science (Collins and Evans, 2002). The essence of this turn has been a shift away from debates over the ideal form that science should take so as to guarantee that scientists have special access to the truth. The new focus has been upon how science is practised and what this means for the position of science in society, such as in making decisions. As I review below, this has revealed that

1. science as practised (e.g. the conduct of a research project) is not necessarily the same as science as it is portrayed (e.g. in the structure of a scientific article) and how science is practised shapes fundamentally the scientific knowledge that is generated;

2. policy-making is not simply based upon the results of scientific enquiry; and

3. "scientists" are not the only individuals within society that have scientific expertise; rather, scientific knowledge is more widely distributed amongst those who have a particular experience or interest of the problems that commonly interest scientists.

Collins and Evans (2002) conceive this as a turn away from a "first wave" of science studies, concerned with how to maintain science as the basis for difficult policy- or decisionmaking, towards a "second wave" of science studies, that challenges the traditional privilege accorded to science in decision-making. This second wave showed that scientific knowledge was, in some senses, "constructed" by the specific actions and practices of the scientists involved in producing it, so challenging the ideal notion that through the separation of science from society, it is possible to provide objective accounts of those questions of interest to society. As such, the second wave was largely analytical. What it was not, and 
what Collins and Evans argue that it should be, was normative, that is, prescriptive of how science should be practised given what the constructivist account showed. Without what Collins and Evans describe as a "third wave", there is a risk of rejection of scientific knowledge as a critical contributor to the difficult decisions that have to be made in an era of potential environmental crisis (see also Demeritt, 2006). A third wave of science studies is needed that prescribes how best to sustain the contribution that science has to make to societal decision-making.

The primary aim of this paper is to think through the possible contribution of hydrological science to understanding, and perhaps predicting, a socio-hydrological world. First (Sect. 2), I begin by illustrating, using hydrological examples, the three points above, so as to consider how predictive socio-hydrological science should be practised to establish its legitimate contribution to policy- and/or decision-making. At the start of a new decade of hydrological science concerned with prediction, we have a profound opportunity to do this. The second (Sect. 3) provides an empirical example of the construction of hydrological knowledge in practice, by detailing the history of roughness parameterisation, using parameters like Manning's $n$, in hydrological and hydraulic models. As a third point (Sect. 4), I use this example to show why we need a "third wave" of science studies if the evolving discipline of socio-hydrology is to fulfil its potential, that is, we need to rethink the traditional view of the relationship between hydrological expertise and society. Fourthly, in Sect. 5, I introduce a set of principles that might contribute to such a rethinking and illustrate their implementation through a specific case example. The paper contains a mixture of review as well as primary evidence, the latter obtained from a project concerned with new forms of participation in flood risk management (Lane et al., 2011b).

\section{A constructivist account of hydrological practice}

In this first section, I draw directly upon science-technology studies to introduce to hydrologists the case for a constructivist account of science in general and hydrology in particular. At the outset, this engages with a set of literature that will not be familiar to the hydrological scientist, but which is important because it shows that the constructivist account is one that parodies elements of conventional scientific method in general, and our practices as hydrologists in particular: that is, it is based upon empirical observation of science in practice, in the same ways in which a hydrological scientist might focus upon, for example, the observation of river flow. Whereas the subject of hydrology tends to be "things to do with water", the subject of STS as considered in this paper is "hydrological science and how it is practised". I make three points. The first draws upon work done largely in the sciencetechnology studies community, which includes philosophers, sociologists, historians and geographers amongst others, that has sought to understand how scientists construct knowledge about the natural world. The work has shown that rather than scientific activity simply finding out about the real world, science as a practice involves defining what that world is, as we come to know it. The second considers evidence of how hydrological knowledge is used in decision-making, which questions the traditional assumption that such knowledge can be a simple basis of informing difficult policy decisions. The third demonstrates the deep and sometimes profound knowledge of hydrological science that those often labelled as "lay people" may have, and which suggests that there is a much broader community of potential hydrological scientists who have to be considered in a socio-hydrological account. Each of the three accounts is well developed in science-technology studies (STS) in general, and so the review is brief. As my examples will show, hydrology has generally escaped such analysis as compared with environmental concerns (e.g. climate change; genetically modified organisms and the food chain; nuclear power) that share the similar challenges of understanding complex, open systems (Wiman, 1991).

\subsection{Framing and the construction of scientific knowledge}

My first entry point can be traced back to a Polish scientist, Ludwig Fleck who in 1935 published a book Genesis and Development of a Scientific Fact, translated into English in 1979. This book was an historical account of our scientific understanding of the disease syphilis, important because it showed how both thought and experience combine to construct scientific knowledge (Rosenkrantz, 1981). Fleck introduced the idea that our general conceptions frame scientific practices (e.g. what to measure, how to measure) just as what we do shapes those conceptions. His ideas predated but parallel those of Kuhn (1962) in that Fleck talks of "thought collectives" or "thought styles" as the dominant conceptions that frame and constrain scientific practice: that is, we often work within communities (research groups, for example) that tend to define or to frame the kinds of approaches that we used. Fleck's work is a major precursors of the constructivist account of scientific knowledge as: (1) it challenges attempts to define science as a simple process of correcting concepts, ideas or theories (whether inductively from observations, deductively by validating theories or by falsification through showing extant theories to be incorrect); and (2) it shows how a combined historical and ethno-methodological approach can help to understand how scientific knowledge is constructed. That is, we can study how science is practised through observing it, as we might study infiltration of water into a soil, spatial patterns of surface runoff etc. Whilst Fleck's concern was, in particular, an historical account of why and how the Wassermann Reactor was identified in 1906 as a test for syphilis, it also drew upon his own experience (i.e. it was auto-ethno-methodological) as a bacteriologist. This emphasis on experience has become central to many 
constructivist accounts in that, in a way that parodies the traditional activities of field hydrological scientists, they are based upon explicit observation of science in practice.

One of the first attempts to reveal science as practised is found in the book by Latour and Woolgar (1979), Laboratory Life: The Social Construction of Scientific Facts. Latour and Woolgar argue that a focus on practice is necessary because the publication of "systematic and tidied research reports" (p. 29) does not illuminate the realities by which knowledge comes about, and hence precisely what the status of scientific knowledge is. Through an anthropological study of medical scientist Roger Guillemin's medical laboratory at the Salk Institute, California, Latour and Woolgar make four (amongst other) important observations. First, they showed that the material, technical and human resources of the laboratory determined the challenges afforded in practising science and the facts that were found, whether through the logic of deductive reasoning or the observations behind inductive reasoning. There was clearly an act of framing of knowledge by the resources assembled in the laboratory. Second, they considered what constitutes facts in a laboratory setting and they noted that in scientific papers produced by the laboratory, it was possible to identify a "continuum of facticity" (p. 76) between those statements that could be taken as given (facts) and those that were speculative. The work of the laboratory was to move statements from speculation to given. Third, they observed that "reality" and "fact" was not necessarily the same thing. There were statements used in the laboratory that were "considered too costly to modify" and that these "constitute what is referred to as reality" (p. 243) in the laboratory, regardless of their status as facts. I will illustrate this point with respect to the widely used roughness parameter, Manning's $n$ (in Sect. 3). Fourth, they showed that facts emerge in networks of scientists (and the things that they study) and that it is these networks that give facts their meaning. Without the network, the meaning of a fact may evolve or even take on a new form: the networks produce this meaning; and the meaning only survives as long as the network can maintain it.

The key implication that arises from these four points is that the claim to scientific authority that arises from pursuit of a rigorous scientific method, one reproduced in the pages of scientific papers and reports, cannot be sustained. Scientific papers are, at once, both a valuable outcome of scientific activity (new scientific knowledge) but also a misrepresentation of how that knowledge is produced in practice. The Latour and Woolgar (1979) study stimulated both: debate over method (e.g. Lynch, 1982) and substance (e.g. Tilley, 1981; Stewart, 1982) but also a wave of similar studies of scientific practice (e.g. Shackley et al., 1999 in relation to climate change); and an extension to consider technology, the latter showing that the same argument developed for a sociology of scientific knowledge could equally be used in a sociology of technological innovation (e.g. chapters in Bijker et al., 1987).
There is now a set of studies in the environmental sciences, still relatively small, that have sought to develop Latour and Woolgar's ideas so as to understand how environmental knowledge is produced, both in general, and with reference to environmental prediction in particular (e.g. Shackley et al., 1999; Lahsen, 2005; Demeritt, 2006; Sundberg, 2009; Brysse et al., 2013). Latour, who remains one of the key researchers in this field, also came close to the domain of hydrology when he joined a scientific expedition to the Amazon concerned with understanding the dynamics of tropical rain forest expansion and contraction at its margins with savannah: where is the boundary and how is it moving (Latour, 1999a)? Latour's (1999a) work provides some key ideas here for how hydrology is practised, that are expanded on in Sect. 3. Latour describes how a how a botanist, a soil scientist and a geomorphologist tease out, selectively and in a single geographical location, a set of relationships from an environment that at first glance appears to be disorganised and beyond explanation, not unlike classic challenges in field hydrological science (e.g. complex space-time patterns of soil moisture distribution). Latour notes that each scientist brings to the research process particular kinds of "inscription devices", those are objects (e.g. equipment, measurement protocols) that make the field site measurable according to the wider approaches and presumptions associated with each scientist's discipline. The devices (e.g. a standardised soil tensiometer) are critical, as they homogenise the study of very different field environments, making them comparable both to one another and to the academic world of that discipline. The field site can be made knowable on the basis of each discipline's dominant terms of reference: the "référence circulante". To arrive at this point, the complexity of the real world is progressively reduced (as it is in the laboratory) through a series of steps of "translation" so as to lose its local focus and to amplify its general representativeness and eventually to allow it to be written in a form typical of a "scientific" document such as a research paper. Latour (1999a) argues that understanding what is being done here requires both a realist and a relativist perspective, realist because scientific activity is constrained by the real world (Gooding, 1990) and these constraints survive through the translation; but relative because, unavoidably, what we know about the real world is constructed, or framed, through the process of translation, that is, science as practised.

If we think about what this might mean in relation to hydrological science, Latour and Woolgar (1979) and Latour's subsequent work (1999) raise questions as to: what are those components of hydrological investigation that are proving too costly to modify and why are they so fixed? (candidates might include the Nash-Sutcliffe index of Efficiency or the topographic index, for example); how do we choose field sites and translate them into generic findings, and how is generalisation done more generally?; and what role does practice play in shaping hydrological knowledge? In answering each of these questions, we have to consider how it is that 
the findings of hydrological activity are framed by the decisions that hydrologists make and, through this framing, particular accounts of the hydrological world become dominant over others. It implies a need for empirical observation of hydrology in practice, something that is illustrated in Sect. 3.

\subsection{Science in decision-making}

The second element of the constructivist account of knowledge is concerned with observations of how scientific knowledge translates into decision-making. Here, I define decisionmaking broadly, to relate to those situations where there is some kind of translation of scientific knowledge into decisions that have to be made to develop or to modify policy, as well as in relation to more specific cases, where a particular scientific finding is used to inform a particular management intervention. As with previous sections concerned with scientific practice, this second element has also been strongly empirical (see for example, Wynne, 1992; Demeritt, 2001, 2006; Bickerstaff and Simmons, 2004; Pielke, 2007; Liken, 2010; Oreskes and Conway, 2010), that is, the relationship between science and decision-making has been traced historically and used to challenge the simple assumption that scientific knowledge translates simply, or "linearly" into decision-making, the "linear model". Under this heading, there are three broad elements of critique (Beck, 2011): (1) that science produces certainty by reducing uncertainty, and so can aid the taking of difficult decisions; (2) that scientific knowledge can be a basis of resolving political discord; and (3) that through the exclusion of politics from science, scientific knowledge becomes a more rational basis for decision-making than other kinds of knowledge.

\subsubsection{Science and the assumption that scientific research reduces uncertainty}

Wynne (1992) provides what has become a classic analysis of uncertainty surrounding science. He argues (see also Beven, 2008) that uncertainty should be unpacked into a typology of

1. risk (the quantifiable probability of an event happening), elsewhere known as aleatory or stochastic uncertainty, but that can be quantified;

2. (true) uncertainty (known but unquantifiable probabilities), again that may be aleatory or stochastic, but where the uncertainty cannot be quantified;

3. ignorance (the not yet known but potentially knowable, often described as "we don't know what we don't know"), also known as epistemic uncertainty; and

4. indeterminacy (that which cannot be known), sometimes also referred to as Knightian uncertainty.

Wynne (1992) argues science may contribute to the quantification of risk (Type 1) and the analysis of uncertainty
(Type 2) in ways that make it better known. Yet ignorance or epistemic uncertainty is endemic, not least because science is actively involved in creating products and processes whose effects may not be knowable before their creation (e.g. genetically modified crops). Indeterminacy questions the very ability to analyse and to predict certain things, notably at the interface with the social world.

Wynne illustrates this typology by tracing the relationship between science and decision-making postChernobyl (1986) radio caesium fall-out and its impact upon upland soils in the UK. Scientists initially thought that the radio caesium would be rapidly immobilised on the basis of previous experimental testing. Still it was not, because the soils exposed to the heaviest fall out were acidic, whereas the experimental soils were alkaline. The experimental results did not translate completely beyond the experimental case. The initial failure of scientists to conclude that the radio caesium would remain mobile was a classic example of scientific progress: a basic theory based upon prior understanding proved to be incorrect, and so new scientific understanding was obtained.

The progress of learning through mistakes, described above, might be used to conclude that science has reduced uncertainty, but three points challenge the notion that science can aid difficult decision-making by reducing uncertainty. First, it is well-established that science advances through a process of examination, revision and reexamination (Oreskes, 2004), a process in which scientific progress is most rapid when existing knowledge claims are no longer found to hold. If science proceeds through falsification, and this falsification happens publically, then the claimed authority of science may become questioned in a very public way. Wynne (1992) reports exactly how this happened amongst local communities in his study when radio caesium was not rapidly immobilised, and wider concerns emerged regarding the general authority of scientists regarding the safety of Sellafield, the adjacent nuclear waste processing plant. The same occurs with flood risk maps that are generally right in that they can achieve inundation patterns that are 80 to $90 \%$ accurate (e.g. Yu and Lane, 2006) but wrong in the detail that matters in relation to those who live with flood risk (the remaining 10 to $20 \%$ ) as well as ineffective in scientific terms, as a means of enabling model calibration (Stephens et al., 2012). Thus, such maps can be the origin of significant hydrological controversy both within and beyond scientific communities (Lane, 2013). If the nature of science is to proceed through showing elements of scientific knowledge to be incorrect, then this implies the translation of supposed certainties into supposed uncertainties which in turn motivates new scientific enquiry. Science proceeds by producing uncertainty and not certainty.

Second, the nature of "ignorance" is that we do not know what else we do not know, especially in environmental systems where there may be both an incomplete knowledge of critical processes and where the influence of local or 
contingent conditions may significantly shape environmental response (e.g. Wiman, 1991; Trudgill and Richards, 1997), as with Wynne's example. The environment has a complexity that commonly places research far from the closed world of the laboratory (Irwin, 2001). The certainty that results, then, is largely conditioned upon the assumptions needed to realise said certainty, and I consider this issue in relation to predictive modelling below. Alongside scientific certainty is the production of a series of epistemic uncertainties associated with the need to make that science certain; yet, vagaries of the environment serve to make scientific knowledge inherently uncertain.

Third, evidence shows that when policy is faced with new scientific findings, that policy can remain relatively stable, because it is sustained by and in turn sustains a suite of other issues which constrain the extent to which new scientific knowledge can be translated into policy. That is, even if the above two concerns regarding scientific uncertainty can be overcome, the scope of scientific enquiry rarely extends to the full range of constraints that may make a particular decision more or less acceptable. For instance, Lane et al. (2011a) considered the history of the $20 \%$ uplift in peak flow magnitudes that flood risk modellers were expected to use in England and Wales up until recently to account for possible future climate change. They show that new work that challenged the UK-wide application of this uplift (for catchments of different scales in different geographical regions) failed to change an established policy. The reasons invoked for this were largely related to a societal decision about the need to be conservative regarding safety in relation to climate change impacts and neither the scientific findings nor the associated uncertainties themselves.

In summary, this sub-section shows that we cannot assume that science produces simple certainties by reducing uncertainty: science proceeds by discovering its own uncertainties; in environmental systems, it commonly relies on assumptions that will produce epistemic uncertainty and that, even if these concerns can be resolved, scientific knowledge is rarely the only information that informs policy-making. The latter point leads directly into the observation that science cannot be assumed to be a sufficient basis for resolving political discord.

\subsubsection{Science and the resolution of political discord}

It is commonly assumed in the linear model of science into decision-making that science is a means of resolving political discord. The assumption here is that faced with difficult decisions, science can provide an objective guide to what decisions need to be taken. A number of explicitly hydrological examples regarding conflicts over water have challenged this view (e.g. Kropp, 2005; Wesselink et al., 2009; Weber et al., 2011; Austin et al., 2012; Smith et al., 2012). For instance, Kropp (2005) describes the debate over renewal of water license abstractions for hydroelectric power exploitation in the
River Isar, Germany. This was initially a tri-partite debate between the hydropower company, state authorities and the Isar Alliance, a network of conservation interests, environmentalists, political parties etc. Debate between them was unable to agree on a way forward and so a Restwasserstudie was commissioned (a "remaining water study"). This report created more and not less controversy regarding for example water quality standards and the objectives of water conservation, causing Kropp to conclude (2005, p. 490) that "once again, the modern hope of depoliticising a conflict through the involvement of scientists and expertise, that is, negotiations of facts instead of values, proved vain.” Kropp's study illustrates clearly the point that even with scientific knowledge there are steps in the translation of this knowledge into decisions that are negotiated and are concerned with values. In turn, this causes us to question the assumption that science alone can provide a rational basis for decision-making, that is, it is necessary but not sufficient.

\subsubsection{The rational basis of science}

It is often argued that for science to provide a rational basis for making decisions, the scientist must exclude the context, their values, interests and beliefs, within which they perform their research. This can be a challenge, especially when scientists are working in highly visible research areas and are increasingly required to frame their research in terms of benefits to society. Evidence also suggests that the goal of trying to do this can actively shape scientific outcomes: not only is it hard to be rational in relation to highly emotive research questions, but the act of trying to be so changes what scientific knowledge is generated. In relation to climate change, for instance, Wynne (2010) and Brysse et al. (2013) have shown that through attempts to be objective, rational and sceptical, climate scientists have tended to err on the side of less rather than more alarmist predictions of future climate. Wynne (2010) argues that a series of "cultural-economic habituated practices and global economic relations" (p. 299) has caused climate change scientists to focus upon future mean climate change (e.g. temperature rise) rather than the more alarming and more certain climate extremes: "only 'digestible' and (thought-to-be) 'manageable' future climate changes are recognised as scientifically accredited" (p. 297) and therefore worthy of scientific investigation.

In a more directly hydrological example, Lane et al. (2011a) show how the practice of flood risk modelling in the UK has had to be constrained by a series of political decisions surrounding how cost-benefit analysis is to be implemented (e.g. the time horizon over which costs and benefits must be integrated). Whilst the output, then, is a series of flood risk maps and, in turn, a prioritisation of where to invest in flood risk management, these supposedly objective findings hide a series of decisions necessary for their making that have no basis in flood science itself. It is extremely misleading to argue that such outputs are "rational" and "objective" 
because they are "scientific", when they obscure a series of deeper social and economic assumptions, which are rarely exposed in the maps themselves, assumptions that are necessary to make the maps. To summarise, as Irwin (2001, p. 74) notes "... the "facts" of environmental matters do not speak for themselves: instead they are actively created and interpreted. Similarly, nature can no longer be represented as an external category. Statements about the natural world represent social and institutional constructions."

\subsubsection{The co-evolution of science with policy}

Concerns over the supposed certainty of scientific knowledge, evidence that science is not sufficient in resolving political discord, and questions over the extent to which scientific knowledge can be a rational basis for decision-making suggest that science does not flow linearly or simply into decision-making as might be assumed. To replace the linear model, it is appropriate to see science and society, including decision-making, as in a state of co-evolution, with one impacting the other. This ties directly into the notion of socio-hydrology, with its emphasis upon the co-evolution of water with society but suggests that hydrological scientists cannot claim to be separate from this system: the practice of hydrological science, in a socio-hydrological framework, is both constrained and enabled by the socio-hydrological system within which it is practised, and the system will evolve in response to the practice of hydrological science as part of an evolving process of social change.

If this is the case, then we might expect there to be at least some geographical differentiation in the scientific and technical cultures that arise surrounding water: that is, the production of distinctive socio-hydrological systems each on their own path trajectory, as they evolve. Such differentiation was demonstrated in a series of articles by Bijker (2007a, b). He poses a simple question: "How is it possible that the USA failed to keep New Orleans dry, when large parts of the Netherlands can exist below sea level?" His argument is that, of course, there are differences in the geographical and geological setting of the two countries (the Netherlands is a more "watery country" than the USA, in Bijker's terms). He shows however that such a conclusion is insufficient, not least because the science of land-ocean reactions does, in theory, follow a near-universal set of process laws. Yet, he argues that both countries have evolved completely different socio-hydrological systems, ones that shape exactly how scientific and engineering understanding is translated into water management. For instance, the Dutch have evolved a system of highly centralised action, built upon the collaboration necessary under penalty of being flooded but also the wider belief in the malleability of society through state action. In turn, this has defined the scientific priorities of Dutch water management and produced a series of approaches to water management that have sustained strong state action. Rather than science flowing linearly into the shaping of particular technological cultures and policy decisions, science and technology have mutually co-evolved to create very different technological and policy settings. These contain a certain amount of resistance to change, e.g. in response to scientific development, because of the extent to which they are strongly inter-related. Understanding how socio-hydrological systems are made requires us to look carefully at not just how hydrological science is practised, as Sect. 2.1 suggests, but also at how (hydrological) scientific practices have evolved within socio-hydrological systems, in ways that are mutually constitutive of those systems.

\subsection{Certified and non-certified hydrological experts}

The third direction in a constructivist account of hydrological practice recognises that expertise in hydrological processes and systems is much more distributed than might be thought. In any area of science that is strongly bound with society (e.g. hydrological science) then problems will arise if scientific knowledge (and its emphasis upon impersonal observation) becomes detached from meaning (and its embedded experience) (Jasanoff, 2010). Jasanoff (see also Wynne, 2010) takes the example of climate change, where the work of the Intergovernmental Panel for Climate Change successfully established climate change as a global problem but in doing so they distanced climate change from its embedded experience, thus undermining those social institutions and ethical commitments that rely upon "the subjective, situated and normative imaginations of human actors engaging with nature" (p. 235). Jasanoff argues that it is precisely these social institutions and ethical commitments that need to evolve if there is to be a sufficient response to the challenges posed by climate change. There are two distinctive interpretations here: (1) those who live with environmental concerns may hold substantial knowledge of those concerns, acquired through experience, that is in some senses no different from the ways in which scientists might obtain that knowledge; and (2) those institutions and commitments that we will rely upon to manage those concerns are sustained by more than just the knowledge that science can provide.

\subsubsection{The distribution of hydrological expertise}

The notion that human actors, through their engagement with nature, may have substantial expertise is a direct challenge to traditional approaches that have followed an approach to science known as the "deficit model" (e.g. Eden and Tunstall, 2006; Petts and Brooks, 2006). The deficit model assumes that science is sufficient but the public are deficient (Sturgis and Allum, 2002) and, with distinct parallels with the linear model of science into policy, scientific knowledge needs to be transformed into public understanding through public education. The Royal Society of England and Wales sees this as the twin responsibilities of a scientist: "The first is to attempt an accurate assessment of the potential implications for the 
Table 1. A comparison of non-certified expert knowledge, as recorded during an experiment in public participation in flood risk management (Lane et al., 2011b), with the equivalent description that a certified expert (a scientist) might make of the same phenomenon. CG stands for "Competency Group" (see below) and the number refers to the meeting number.

\begin{tabular}{ll}
\hline Non-certified expert knowledge (local people) & Certified expert knowledge (scientist) \\
\hline CG1: "Because of course it depends where you are, because if you are closer to the & $\begin{array}{l}\text { The depth dependence of frictional } \\
\text { resistance in river-floodplain flows, an } \\
\text { assumption that is central to the diffusion } \\
\text { wave approximation of the 2-D shallow } \\
\text { is spreading out ... it doesn't tend to be moving at great speeds, it is just sort of } \\
\text { spreading out." }\end{array}$ \\
$\begin{array}{ll}\text { CG2: "Logic says that you have got to work out the contours and work out which is the } \\
\text { lowest lying land. I suppose there must be some sort of formula to work out exactly the } \\
\text { volume of water you are expecting to come down and therefore to what volume it will } \\
\text { fill that level." }\end{array}$ & $\begin{array}{l}\text { Poupled to the principle of volume } \\
\text { conservation for an incompressible fluid }\end{array}$ \\
\hline $\begin{array}{l}\text { CG2: "But Pickering is a slower process I think, than Sinnington is. And it is not such a } \\
\text { sudden thing. I mean you can see Sinnington rising. I don't think you can here so } \\
\text { much. [because] Pickering Beck goes much further north, and it is gathering more } \\
\text { water." }\end{array}$ & $\begin{array}{l}\text { Hydrograph attenuation } \\
\text { CG2: "The other thing that is important is that we have got heavy clay soil. But the }\end{array}$ \\
$\begin{array}{l}\text { soils vary in different parts, whereas of course the clay soil around Great Barugh } \\
\text { means that other areas are more sandy perhaps and drain more easily." }\end{array}$ & $\begin{array}{l}\text { Infiltration and runoff generation as } \\
\text { controlled by soil type }\end{array}$ \\
\hline $\begin{array}{l}\text { CG3: "So to protect Pickering, the nearer the dams are to Pickering the better?" (Local } \\
\text { member 1) "Well yes certainly" (Local member 2) }\end{array}$ & $\begin{array}{l}\text { Design of flood storage schemes to remove } \\
\text { flood wave peaks }\end{array}$ \\
\hline
\end{tabular}

public. The second is to ensure the timely and appropriate communication to the public of results if such communication is in the public interest" (Royal Society, 2006, p. 5).

Callon (1999) argues that the "public education model" relies upon intermediaries (e.g. public authorities) that are the contact points between scientists and the public and that it can only succeed when these contact points are based upon relations of trust. Problems arise when such notions of trust become damaged and a major reason for such damage is that through their day-to-day experience of nature, quite substantial expertise may develop: most publics have elements of expertise because they possess "specific, particular and concrete knowledge and competencies, the fruit of their experience and observations" (Callon, 1999, p. 85). As the knowledge that science can deliver about the real world is inevitably incomplete (see, for example, Wynne, 1992 and the example of flood risk maps described above), it is always at risk of becoming contested when it is confronted by public expertise in particular situations. Empirical evidence suggests that such expertise is much more broadly distributed than has hitherto been thought (e.g. Wynne, 1992; Darier et al., 1999), prompting some (e.g. Collins and Evans, 2002) to make the distinction between certified knowledge (that of scientists, policy-makers etc.) and non-certified knowledge (that of publics). The notion of certification implies a transfer of legitimacy and hence a privileged position of some kinds of knowledge over others.
The existence of non-certified hydrological knowledge has been shown in a number of studies. In general, river basin management has been an area of experimentation with respect to new forms of public participation (e.g. Johnson, 2009). In a project concerned with new forms of public participation in flood risk modelling, Lane et al. (2011b) were able to show that local flood victims had developed a rich understanding of the fundamentals of hydrology and hydraulics (Table 1) and that this was much more than just "local" knowledge (e.g. Callon, 1999): it was universal in the sense that it referred to generic processes. Through interviews with the participants, Lane et al. (2011b) also showed that this knowledge had not come from formal training, nor was it acquired from a singular local place where flooding had been experienced. Rather, it was the accumulation of sometimes many decades of living with water, a process of accumulating knowledge through experience, not dissimilar to the scientist who progressively accumulates knowledge through both formal training and the practice of researching hydrology.

The recognition that hydrological expertise is more distributed than is commonly assumed challenges the notion that only scientists are capable of constructing and acquiring scientific knowledge and hence that only scientists have the knowledge that can be used in informing policy. Callon (2005) goes one step further in using the notion of disability to describe how both publics and scientists are disabled from "reasonable arbitration", that is the ability to evaluate a claim, observation, statement etc. in an independent 
and biased manner. For Callon, it is a question of framing. Scientific activity is concerned with the transformation of the real world into objects (e.g. a hydrological model or flood inundation maps) that can be used to generate knowledge. Strictly, the knowledge that we acquire is about the assumptions made in the framing, as I discuss in Sect. 2.1, and not necessarily the world itself, although we may embark upon a series of measures to make sure that the framing conforms with the real world (e.g. its validation) or, if not, to force the framing to conform with the real world (its calibration). These framings are produced by our own experience (that is, they have a history), our position with respect to other framings and they evolve through our scientific practices and hence define our futures as scientists (see also Lane, 2012).

Callon's (2005) point is that we are often disabled in the evaluation of our own framing because we are locked into it, something that has been confirmed by empirical research. For instance, Lahsen (2005) showed how climate modellers were often ineffective at identifying flaws within their own models. In one sense, such identification may be achieved through effective peer review processes, but when whole scientific communities are locked into particular practices, even those processes may not be effective. Smith et al. (2012) show how flood maps may become objects that serve to legitimise the exclusion of wider debate between those implicated in decisions to which those maps refer. In Callon's terms, the maps may become disabling devices. It is for this reason that Callon (2005) advocates greater rather than less public involvement in scientific practice because, for the public: "It is their initial ignorance that enables them to dare to explore new paths and to develop original competencies. Democracy is therefore entirely an affair whose success depends on the engagement of disabled persons. This engagement protects the issue from the risk of being hijacked ... by elites with no ambition other than putting it at the service of their own interests" (p. 313).

\subsubsection{Embedding knowledge and the translation of science into policy}

A failure to recognise Callon's observation is not simply a question of democracy but also one regarding the effective translation of science into policy. Here, I argue that it is not just a question of recognising the distribution of scientific knowledge but also that the meaning of that knowledge comes only from the way in which it is embedded within the lives that hold it. For instance, particular scientific framings often imply certain expectations of people, that they have the necessary "capital" (social, economic, cultural) to cope with its expectations. In flood risk mapping and hydrological forecasting, the classic example is that those at risk from extreme flood events will have the capacity both to prepare themselves for future flooding and to act when a particular warning is issued. Research has shown that this is anything but the case (e.g. Mustafa, 2005); not that the associated hydrological science is wrong, nor that flooding is not a potential risk, but rather that it is not a risk that can be rationalised and acted upon when faced with a series of much more serious and pressing risks. The implicit adoption of particular framings of a problem and their imposition upon the public may then undermine the very real risks that the public itself faces (e.g. Wynne, 2010). As Bijker (2004, p. 381) notes, then, the merit of science "is accomplished in social practice and not bestowed upon science by philosophers or others." The argument here is that not only should the basis of scientific knowledge be more distributed but also that scientific knowledge only has meaning within those communities who have to live with its consequences. If a discipline like socio-hydrology is to be more than just analytical, we need to think through the very assumption that its practice can be left to those who hold certified knowledge alone: where and how socio-hydrology is practised also needs careful consideration.

\section{Following Manning's $n$}

The first part of this paper has reviewed the three major critiques that arrive with a constructivist account of hydrological knowledge. In this and the next section I want to focus upon predictive hydrological modelling, in the context of these three critiques. My argument follows the structure associated with these three critiques. First, I will begin with a focus upon a particular element of hydrological modelling practice as it has evolved over an extended time frame and, in so doing, I consider Latour and Woolgar's (1979) notion of a "continuum of facticity" that describes the transfer of facts between those statements that could be taken as given and those that were speculative. For Latour and Woolgar (1979), the work of the laboratory was to move statements from speculation to given. In contrast with the laboratory, what I want to argue here is that a critical element of hydrological prediction is leaving some statements speculative, what I call antifacts, and I illustrate this using the parameter Manning's $n$, widely used in both surface and subsurface flow routing calculations. Second, I will consider hydrological modelling as a performative practice more generally, one in which modelling can only proceed through a process of framing by society, and so reversing the traditional assumption of a linear transfer of scientific knowledge into policy. I will show that policy is needed to frame exactly how hydrological modelling should be done, something that reinforces the notion of a socio-hydrological system. Third, I will show that the need for policy framing reaffirms the role alternative approaches to the practice of hydrological modelling, especially in the context of the coevolution of hydrological and social systems, ones that are more than just analytical, and more sensitive to the immense power that hydrological science has to influence the day-to-day lives of ordinary people. 


\subsection{The origins of Manning's $n$}

Whatmore and Landström (2011a) consider "the ubiquity of a small, italicised mathematical symbol - " $n$ " - in the working practices of hydraulic modellers" and, in particular, they seek to understand how despite ongoing academic concerns, it remains as "a cornerstone of the working practices of engineering consultants which inform the policy and practice of flood risk". A number of researchers have sought to trace how the Manning's formula came about (e.g. Dooge, 1992; Whatmore and Landström, 2011a). Reading Manning's (1891) paper shows that it came from seven existing formulae used to estimate mean section velocity from its hydraulic radius and energy slope. Manning arrived at two results, and concluded that if the exponent of slope in the estimation is constant at 0.5 then the relationship should take the form

$V=C s^{1 / 2} R^{x}$,

with $C$ the "Manning constant" and $x=4 / 7$ on the basis of the seven formulae used. Then, in a second step, Manning set about determining $x$ using experimental data from Darcy and Bazin (1865). These produced ranges of $x$ from 0.63510.6778 and $0.6176-0.6733$ for cement-lined and cementsand lined semi-circular channels respectively. Higher values $(0.7635$ and 0.8395$)$ were required for gravel-lined channels. Through a critical approximation, Manning settled on a mean value, $2 / 3$, because this was "sufficiently accurate" (Manning, 1891, p. 175). Manning then compared this formula with 170 experiments from 5 authors, including Darcy and Bazin (1865) and found that with the exception of data from the Mississippi, the formula performed sufficiently well to be generalised. He attributed the problems with the Mississippi data to concerns over measurement (Manning, 1891): "It is very doubtful whether the measurement of such a small quantity was possible in the case of the Mississippi, notwithstanding every care which could be taken by the able conductors of the experiments, particularly as the transverse surface of the river is stated to have a curvature of 11 inches." The other element of Eq. (1) that needs attention is $C$ which actually confuses two elements: (1) a coefficient that converts between different units (e.g. metric and imperial); and (2) a roughness factor, $n$. Whilst others had already applied the label $n$ to a roughness factor ("Kutter's $n$ "), Willcocks and Holt (1899) presented the Manning formula as it has come to be known in metric units as

$V=s^{1 / 2} R^{2 / 3} / n$.

Although $n$ is formally Kutter's $n$, it was shown to be equivalent to roughness factor values estimated by Manning, and in the first part of the 20th century, $n$ became referred to as Manning's $n$ (Dooge, 1992). The steps taken to arrive at Eq. (2) are important because they lead to a formula for estimating velocity with a single parameter, Manning's $n$, which has no directly measurable equivalent. In returning to Latour's notion of a continuum of facticity, this account shows how Eq. (2) moved from speculation regarding the possible relationships between $R, s$ and $V$, to a given, something that others would go on to describe as a "law" (e.g. Govindaraju and Erikson, 1995; Zhang and Savenije, 2005). Nonetheless, it has also retained something that is speculative. I will now show that the history of Manning's $n$ becomes a history of its resistance to moving along the continuum of facticity and that, as such, its raison d'être is as an "anti-fact".

\subsection{Parameterising Manning's $n$}

Manning's (1891) original objective was to develop a "rational theory of the motion of water in an open channel" (p. 171) with the "desire of reconciling as far as possible those apparent differences of opinions which have existed amongst hydraulicians" (p. 171). Equation (2) reconciled those differences both in terms of the structure of the equation but also through introducing a parameter, $n$, that had already been calibrated. Calibration here means, in effect, taking measures of $V, R$ and $S$ for a number of streams and hence estimating $n$ (e.g. Ganguillet and Kutter, 1869; Hering and Trautwine, 1889; Scobey, 1915; King, 1918). This inverse estimation showed that $n$ values varied, yet if Eq. (2) is to be used for estimation, an a priori means of estimating $n$ is required. Reflecting Manning's desire to have a rational theory, Manning's $n$ had to be turned into an inscription device (after Latour, 1999a) that would allow velocity to be estimated. Two broad attempts developed to do this. First, Ganguillet and Kutter (1869) had already begun to create an inscription device, based upon a classification, in their case of rivers, into six classes according to their surface (effectively grain size and presence/absence of vegetation). The number of classes expanded (e.g. to 21 in Horton, 1916) until Chow (1959) presented ranges of $n$ values for 110 classes. The progressive increase in the number of sites was needed to capture the variability of $n$, and Chow's introduction of ranges for any given site characteristic shows early resistance of Manning's $n$ to becoming a fact. Second, even these kinds of tables were hard to use. In a US Geological Survey Report, Barnes (1967, p. 2) wrote: "At the present state of knowledge, the selection of roughness coefficients for natural channels remains chiefly an art ... There are no resistance diagrams or quantitative relationships available similar to those used for steady flow in uniform pipes ... Consequently the ability to evaluate roughness coefficients for natural channels representing a wide range of conditions must be developed through experience."

In practice, the ability of $n$ to become a fact is also dependent upon human experience and, as Latour and Woolgar (1979) showed, the network of practices built up to sustain this experience (Barnes, 1967, p. 3): "For this reason the Survey maintains a program which both trains young 
engineers in the evaluation of channel roughness and tests the accuracy of roughness coefficients by veteran engineers."

Recognising that this is not ideal, the solution for Barnes (1967, p. 2) (and then Hicks and Mason, 1991) was "photographs of channels of known resistance are thus useful in estimating the roughness characteristics of similar channels. The photographs and data presented in this report cover a wide range in conditions."

This book of photographs is a classic inscription device in that it represents an object that a scientist can use to homogenise the study of very different field environments so making them referential to one another, to make them into facts. In the words of Barnes (1967, p. 1): "Familiarity with the appearance, geometry and roughness characteristics will improve the engineer's ability to select roughness coefficients for other channels."

\subsection{Making Manning's $n$ more physical}

The above two strategies leave Manning's $n$ as a purely empirical entity even if, as with Chow (1959), some logical physical principles are being introduced (e.g. a relationship between perceived surface roughness and the value of $n$ required). In 1923, a Swiss scientist, A. Strickler published Beiträge zur Frage der Geschwindigheitsformel und der Rauhigkeitszahlen für Strome, Kanale und Geschlossene Leitungen in the Mitteilungen des Eidgenössischer Amtes für Wasserwirtschaft in Bern, Switzerland. Translated, this means "Contributions to the Question of a Velocity Formula and Roughness Data for Streams". As was implicit in the examples above, Strickler (1923) proposed that Manning's $n$ could be determined quantitatively from the median grain size of the river boundary, so in theory making $n$ into a fact, controlled only by a river's grain size:

$n=a D_{50}^{1 / 6}$.

The logic here rests upon the assumption that the variability in a riverbed's surface increases with some measure of grain size, and this variability should influence surface roughness. In metric units, Eq. (3) defines the dimensions of $n$ as $\mathrm{L}^{1 / 6}$, whereas Eq. (2) defines them as $\mathrm{L}^{-1 / 3} \mathrm{~T}$. Thus, Eq. (3) is modified by introducing the gravity constant and expressing the constant of proportionality in a slightly different way (e.g. Brownlie, 1983):

$n=D_{50}^{1 / 6} / a^{\prime} g^{1 / 2}$.

The combination of Eqs. (2) and (4) results in:

$V=\left(\frac{g^{1 / 2} s^{1 / 2} R^{2 / 3}}{a^{\prime} D_{50}}\right)$.

For some (e.g. Brownlie, 1983; Lebossé, 1991) the Manning equation became referred to as the Manning-Strickler equation (Bertand-Krajewski, 2006). Strickler (1923) provided estimates of the coefficient $a$ in Eq. (3), which can be readily transformed into $a^{\prime}$ in Eq. (4). As French (1985) first noted, Strickler's manuscript, published in German, is somewhat obscure: it was a document prepared for the Swiss Cantonal Authorities in Bern and is difficult to obtain. French also noted that Strickler has gone on to be reported in a multitude of ways and I have shown this in Table 2. There is variance between papers in the grain-size parameter used, the value of the exponent taken ( $a$ or $a^{\prime}$ ) and the units used. Some of the exponents can be shown to be equivalent (Table 2) by correcting for differences in units, but there remains a considerable variability between the estimates of $n$ obtained using different relationships. Thus, whilst Strickler brought in an attempt to control $n$, through relating it directly and continuously, if still empirically, to grain size, this relationship has remained remarkably unstable.

\subsection{Challenges from fluid mechanics}

Manning's own work reflected a continual tension between a desire to bring in rational theory and the need to account for empirical evidence. Writing in 1878 (cited in Dooge, 1992) Manning noted "there are no formulae so useful - I might also say none of any real value - to the engineers, which are not in some degree empirical, embodying facts arrived at by careful experimentation." However, there was another challenge that paralleled the development of Manning's $n$ that comes from fluid mechanics. Darcy's (1856) observations of pipe flow had shown that the distribution of velocity within the pipe depended upon pipe radius, implying that where the diameter was larger the influence of the pipe boundary was lower. This effect is implicit in the Manning equation as the hydraulic radius $(R)$ appears as the numerator and $n$ as the dominator. In 1914, Von Mises referred, for the first time, to the idea that roughness $(k)$ in pipes of radius $(r)$ should be seen as relative: in other words, the energy losses in a pipe should vary as a function of $(k / r)$, so velocity should be some positive function of $r / k$. As Darcy was unable to measure close to the boundary, his inferences about boundary roughness, including determination of his friction factor, did not address specifically the nature of boundary effects. However, subsequent work sought to make the link between boundary influence and velocity, both theoretically and experimentally. Key here is Prandtl (1926) who showed from theoretical analysis that velocity within a column of water (i.e. $u_{i}$ at elevation $i$ above the bed) should vary with the logarithm of elevation ( $y$ ) above the bed if it is assumed that, effectively, the rate of turbulent energy production is a function of the local velocity gradient:

$u_{i}=f\left(\ln \left(y / y_{0}\right)\right)$.

von Karman (1930) verified this experimentally for flow in pipes. Equation (6) introduces the constant yo, strictly interpreted at the elevation $y$ above the bed at which the velocity becomes zero. Nikuradse (1933), who worked under Prandtl showed that, through a series of experiments in pipes 
Table 2. Different forms of the Manning-Strickler equation.

\begin{tabular}{|c|c|c|c|c|c|c|}
\hline Source & $\begin{array}{l}\text { Grain size } \\
\text { parameter } \\
\text { used }\end{array}$ & $\begin{array}{l}\text { Form of } \\
\text { Strickler } \\
\text { relationship } \\
\text { reported }\end{array}$ & Units & $\begin{array}{l}\text { Description of Strickler (1923) } \\
\text { within reports of Strickler's } \\
\text { work }\end{array}$ & Equivalence & $\begin{array}{l}n \\
\text { estimated } \\
\text { for a } \\
\text { median } \\
\text { grain size } \\
\text { of } 0.05 \mathrm{~m}\end{array}$ \\
\hline $\begin{array}{l}\text { Limerinos } \\
(1970)\end{array}$ & D50 & $\begin{array}{l}{[1], a=} \\
0.0390\end{array}$ & $\begin{array}{l}\text { feet } \\
\text { small boulders }\end{array}$ & $\begin{array}{l}\text { Derived by Strickler for stream } \\
\text { beds composed of cobbles and }\end{array}$ & 1 & 0.029 \\
\hline $\begin{array}{l}\text { Simons and } \\
\text { Şentürk } \\
(1976)\end{array}$ & D50 & 0.0474 & $\mathrm{~mm}$ & $\begin{array}{l}\text { Derived by Strickler for a small } \\
\text { flume with bed and sidewalls } \\
\text { pasted with sand }\end{array}$ & 3 & 0.091 \\
\hline $\begin{array}{l}\text { Garde and } \\
\text { Raju (1977) }\end{array}$ & D50 & $\begin{array}{l}{[1], a=} \\
0.0417\end{array}$ & $\mathrm{~m}$ & $\begin{array}{l}\text { Derived by Strickler for coarse } \\
\text { bed streams free from bed } \\
\text { undulations }\end{array}$ & 2 & 0.025 \\
\hline $\begin{array}{l}\text { Richards } \\
(1982)\end{array}$ & D50 & $\begin{array}{l}{[1], a=} \\
0.0151\end{array}$ & $\mathrm{~mm}$ & $\begin{array}{l}\text { Summary of Strickler's data on } \\
\text { gravel-bed streams in Switzerland }\end{array}$ & 1 & 0.029 \\
\hline $\begin{array}{l}\text { Subramanya } \\
(1982)\end{array}$ & D50 & $\begin{array}{l}{[1], a=} \\
0.0474\end{array}$ & $\mathrm{~m}$ & No information given & 1 & 0.029 \\
\hline $\begin{array}{l}\text { Brownlie } \\
(1983)\end{array}$ & $\begin{array}{l}\text { Mean grain } \\
\text { size }\end{array}$ & $\begin{array}{l}{[3]} \\
\text { equivalent to } \\
a=0.0420\end{array}$ & $\begin{array}{l}\text { not } \\
\text { given }\end{array}$ & $\begin{array}{l}\text { Based on data from gravel-bed } \\
\text { rivers and fixed bed channels }\end{array}$ & 2 (if $\mathrm{m}$ ) & 0.025 (if $\mathrm{m}$ ) \\
\hline French (1985) & D50 & {$[1], a=0.047$} & $\mathrm{~mm}$ & $\begin{array}{l}\text { Uniform sand pasted to the sides } \\
\text { and bottom of the flume used by } \\
\text { Strickler }\end{array}$ & 3 & 0.090 \\
\hline $\begin{array}{l}\text { Chanson } \\
\text { (1999) }\end{array}$ & D50 & {$[1], a=0.041$} & $\mathrm{~m}$ & No information given & 2 & 0.025 \\
\hline $\begin{array}{l}\text { Bertrand- } \\
\text { Krajewski } \\
(2006)\end{array}$ & D50 & $\begin{array}{l}{[1], q=} \\
0.0474\end{array}$ & $\begin{array}{l}\text { not } \\
\text { given }\end{array}$ & $\begin{array}{l}\text { Strickler's analysis of } 17 \text { sets of } \\
\text { Swiss data }\end{array}$ & 1 & 0.029 \\
\hline
\end{tabular}

of different diameter coated with sand grains of different but, within each experiment, uniform diameter: (1) $y_{0}$ could be interpreted as the average projection of roughness; (2) this could be taken as the diameter $(D)$ of sand grains used; and (3) as a result of experimental analysis, which produced a constant $A$ in Eq. (5) of value 8.48, $y_{0}$ had to be multiplied to $30 \mathrm{D}$. The integration of Eq. (6) across the flow depth, as Nikuradse did, and noting that his analysis is for pipe flow, shows that the depth-averaged velocity, $U$ is

$U=f(\ln (R / 30 D))$.

Although this result is for a velocity profile rather than a section-averaged velocity, it has introduced a relative smoothness term, $R / D$, the reciprocal of a relative roughness term. Nikuradse (1933) specifically considered pipe flow, but Keulegan (1938) used Eq. (7) to develop a general equation for predicting mean velocity in turbulent open channel flow from $R$ and $D$. By the end of the 1930s, synchronously with development of the Strickler relationship, fluid dynamicists had developed linkages between velocity prediction, the hydraulic radius and the grain size of the boundary layer that had been translated into forms suitable for application to rivers.

\subsection{Keeping the problem practical}

These new physically based representations of roughness had a much stronger theoretical grounding than Manning's equation and would seem to represent a threat to Eq. (2): a reason for rejecting the Manning approach. However, attempts were made to show that the relationships were approximately equivalent (e.g. Pal, 1965). The focus was more on the problems that Eq. (7) and similar relationships represented for specifying $n$ using grain size (e.g. Eq. 4). In his classic study of Brandywine Creek, despite making no explicit linkage to Keulegan's demonstration that relative roughness influenced mean velocity, Wolman (1955) was able to relate $n$ to grain 
size provided he controlled for flow depth effects. By 1957, Wolman was modelling roughness parameters (in this case the Darcy-Weisbach friction factor) as a function of relative smoothness (Leopold and Wolman, 1957). However, as Wolman also recognised (Wolman, 1955; Leopold and Wolman, 1957), determining roughness from grain size, even if corrected for depth effects, overlooks the separate effects of other controls upon roughness (e.g. vegetation, bed forms, channel sinuosity etc.), grouped together by Luna Leopold, in a 1960 paper written jointly with Ralph Bagnold, Lucien Brush and Wolman in 1960, into distortion resistance (that associated with changes in flow direction) and spill resistance (that associated with rapid changes in flow velocity). Both Wolman and Leopold et al. (1960) were clear to point out that: "it is impossible here to evaluate the separate effects of these factors" (Wolman, 1955, p. 21) and "for practical reasons, distortion and spill resistance are largely overlooked because the large-scale and discrete boundary irregularities which cause them in natural channels are not easily described in quantitative terms" (Leopold et al., 1960, p. 112).

Yet, grain size can be measured, that is, it can be effectively used in an inscription device. Wolman (1955, p. 22) wrote "analysis shows that the hydraulic behaviour of "grain size" is a frictional factor, and as such, it is one of several related factors which exercise a frictional resistance. A roughness $n^{\prime}$, although perhaps not the most significant measure of energy and friction losses, is, at present, one which can be obtained under field conditions." Thus, the mid-20th century history of Manning's $n$, as illustrated here, shows how it remained markedly resistant to challenges from the rapidly developing field of fluid mechanics. It did so because its utility was not its theoretical superiority, although it could be aligned with developing theory, but its suitability as something that could be practically inferred from simple grainsize measurements which themselves could be made routine and reproducible. By showing how to make grain-size measurements reliable (in his classic "grid-by-number" sampling paper in 1954) and by following Strickler, Wolman affirmed grain size as an alternative kind of inscription device to photographs (see also Limerinos, 1970), one which allowed $n$ to be proscribed in a generalised way.

Strickler's work was developed explicitly by Limerinos in order to develop an "objective relation between Manning's $n$ and streambed particle size" (Limerinos, 1970, 4) even if it "is not likely that the determination of $n$ values for natural channels will ever be an exact science" (Eq. 6). To do this, Limerinos embarked upon a very careful piece of research design where: "The most important criteria in selecting a site for study was that it be relatively free from velocity-retarding influences other than those associated with the size and size distribution of stream-bed particles" (1970, p. 13); and "sites that had an appreciable percentage of particles smaller than about 3/4 of an inch in diameter were eliminated from consideration to avoid the complication of having bed forms at a site - ripple, dune or plane bed - that varied with discharge"
(1970, p. 14). Here, Limerinos has established a network of suitable (field) laboratories where Manning's $n$ can be tied to measurement protocols that can guarantee an internally consistent objectivity, even if the values of Manning's $n$ that result are biased to the sites used to determine them. For Limerinos, even the measurability had to be reduced to questions of practicality: "The intermediate diameter of the streambed particles was studied because that is the diameter most easily measurable - either by sieve analysis or by photographic techniques - and is the diameter that had been used in previous studies by other investigators" (1970, p. 6).

\subsection{Digital roughness}

The final stage of the history of Manning's $n$ relates to its appearance in prototype one-dimensional numerical modelling codes. The simplest, HEC-2, of these kinds of codes became available in the 1960s, produced by the US Army Corps of Engineers and released in 1966. Commonly called a "step-backwater" model, the codes use the energy equation to calculate water surface profiles from the flow velocity (as defined by a given discharge) and energy losses between sections:

$z_{2}+d_{2}+\frac{\propto_{2} V_{2}^{2}}{2 g}=z_{1}+d_{1}+\frac{\propto_{1} V_{1}^{2}}{2 g}+h_{\mathrm{L} 12}$,

where $z_{i}$ is bed elevation at elevation at location $i, d$ is water depth; $\alpha$ is a coefficient; $V$ is velocity and $h_{\mathrm{L}}$ is the head loss between $i-1$ and $i$. The head loss is calculated from the energy loss due to friction between locations 1 and 2 and the energy loss due to expansion or cross section of the cross section between 1 and 2 . The friction loss is commonly expressed as a friction slope, $s_{\mathrm{f}}$, and commonly uses the Manning Eq. (2), including Manning's $n$. Implicitly, Eq. (8) is represents the ability of a river to convey water where, in order to conserve mass, a decrease in velocity implies an increase in either or both of river width and flow depth. Subsequent models were developed in the 1970s to include more complicated treatments (e.g. to allow for unsteady discharge) but they all share one critical characteristic: the models contain rules that need to represent conveyance, and in practice these are primarily built around the Eq. (2) Manning equation (HR Wallingford, 2001). With this development in the 1960s, Manning's $n$ became implicated in the calculation of water surface profiles in predictive models of flood inundation. It is in this sense that Manning's $n$ has become most clearly resistant to generalisation and where its continued existence is linked to its status as an anti-fact.

In 2001, a UK-government-commissioned report (HR Wallingford, 2001) revealed substantial uncertainty associated with the estimation of Manning's $n$ values in such modelling studies. In a consultation of 71 modellers, $46 \%$ were using tables, photographs or other kinds of guides, $32 \%$ were using experience and $22 \%$ other kinds of methods. The result of this survey, plus a wider literature review was a targeted 
programme of activities specifically to develop a Conveyance Estimation System that would regularise how conveyance estimation was done in general and how Manning's $n$ was estimated in practice. This system was launched in the UK in 2004 and had two elements: a Conveyance Generator and a Roughness Advisor (HR Wallingford, 2002). The basic element of the Roughness Advisor is a method for estimating unit roughness, expressed as an $n$, a basic roughness value that could be combined with estimates of energy losses due to turbulence, secondary circulation and channel sinuosity to estimate conveyance losses (HR Wallingford, 2003). The advisor allows both a description-based and photographicbased selection of $n$. The reason for the choice of $n$ is made clear: it is sustained by a network of existing practice, as HR Wallingford (2004, p. 6) noted: "The use of the Manning $\mathrm{n}$ is widespread and to date, most resistance advice, photographs and summation approaches in the literature are expressed in terms of " $n$ " (Barnes, 1967; Chow, 1959; Cowan, 1956; Hicks and Mason, 1998). The Roughness Advisor is therefore based on an $\mathrm{n}$ rather than a Darcy $f$ or Chezy $C$, to maintain this user familiarity and confidence. This was a critical decision made by the Project User Consultative Group and Expert Advisory Board to receive wider user acceptance."

The $n$ values were obtained from field measurements but also "some of the information in the roughness advisor is derived from expert opinion rather than field measurement" (HR Wallingford, 2004, p. 25). In this sense, the Roughness Advisor is a more sophisticated version of the Barnes (1967) photographs, but with a focus upon only unit roughness. However, the same report also demonstrates some resistance of Manning's $n$ to conform to this advice (HR Wallingford, 2004, p. 27): "Calibration of the flow resistance alters the uncertainty in the estimation of conveyance. Calibration data for flow resistance should supersede the generic, non-sitespecific information in the Roughness Advisor. Calibration may result in a different value for the central estimate of water level for the calibration flow rate and there is no guarantee that a single roughness value will achieve a perfect calibration for water levels and flow rates observed on different occasions (due to natural variability)."

For this reason (HR Wallingford, 2004, p. 32) "The Roughness Advisor enables the user to manually overwrite the roughness values. This is essential for the calibration process. The values entered should be interpreted as equivalent unit roughness values, not the all-encompassing Manning $n$ values ...".

These two quotes show how Manning's $n$ clearly performs a function in computer models that is concerned with more than just describing energy losses: it is needed as a calibration parameter, as a means of representing all those processes in the model not being modelled explicitly (Lane, 2005). Interviews with practising flood risk modellers conducted as part of a wider research project concerned with knowledge production in flood risk modelling (see also Whatmore and Landström, 2011a; Landström et al., 2011a; Lane et al., 2011a) revealed the critical role of this calibration process: “... assuming all my rainfall data is right, and I am confident in the hydrology (and that is a big assumption) what that means is that the model is underestimating the levels and it is too late, so what it probably needs is that I need to raise the channel resistance in that reach. You raise the channel resistance which would tend to put the level up a bit, but which might sort of not give you the right sort of timing. Then you reassess the assumption of the hydrology and you say - well, maybe I got the timed peak wrong on the catchment, so I go and reassess the timed peak on the catchment, so what you end up with is something that looks like that. So you think well, maybe I am overestimating too much so perhaps I will bring my Manning's $n$ down a bit. Got the timing right now. So lo and behold you have got your really good match ...".

This makes the estimation of flood levels critically dependent upon historical data, with one consultant noting (Lane et al., 2011a): "you have a whole raft of other sorts of data, verging from the completely anecdotal: "my kitchen flooded to six inches deep on this day", to - if you are lucky, some aerial photography that shows the extent of flooding during an event. And again we would attempt to use that to calibrate or verify the models performance. When we don't have that data the level of uncertainty significantly increases because you are basing it entirely on the physical assumptions of the model."

This can create particular problems when those data are themselves uncertain: "A job we did not so long ago, we couldn't get one of the records to fit at all, our model kept showing, I can't remember what is was, but something like our levels were half a meter lower than the recorded levels, and we couldn't get it up there at all. And after going round and round for months, it was decided that someone better go out and actually check the recorded level of this gauging station, and it was out by half a meter, so we had been trying to fix, fiddle, change things to match this data which was in fact wrong itself." (Lane et al., 2011a).

These quotes show Manning's $n$ performing a very different kind of role to that of a "fact". On the one hand, the parameter has a history of being made measurable, one of translation from simply a coefficient in Manning's original formulation (Eq. 2); through its empirical classification to allow objective estimation of velocity; through steps to ascribe it more physical significance by recognising grain-size controls; through to sophisticated systems for its estimation that can insure comparability between scientists' calculations; ending with automating those processes used to define it. However, the last part of this section shows its ultimate resistance to transition along Latour and Woolgar's (1979) continuum of facticity. Despite its theoretical inadequacies and better ways of handling roughness (e.g. Ferguson, 2007), Manning's $n$ remains a parameter that is hard to avoid in the mathematical modelling of rivers. It retains this status, partly because it is an accustomed parameter, sustained by 
a network of experience, the familiarity and confidence surrounding its use, but partly because it is the perfect anti-fact in modelling practice. That is, it serves a role as something that has almost no directly derivable physical measure, it can only be derived from empirical relationships with other parameters (e.g. grain size) that are themselves unstable (e.g. as a function of discharge, or position within a river system) and model predictions are extremely sensitive to its specification. As soon as Manning's $n$ becomes locked into an inscription device (a table, photographs, a software system) it can no longer provide its critical function, as an effective parameter (see Beven, 1989 for discussion of this notion), in compensating for all the other simplifications and inadequacies in hydraulic models. It is no longer available to make the model perform.

\section{From Manning's $n$ to performing hydrological prediction}

The history of Manning's $n$ ends with the widespread use of a parameter that can be used to optimise model predictions through a process of calibration. It is possible to imagine the same kind of analysis being undertaken, albeit over different kinds of time frames, in other areas of hydrological prediction (with reference to the Topmodel $m$ parameter, the widespread adoption of Gumbell-type distributions, the persistence of particular methods of assessing flood inundation etc.). However, it also points to a wider issue relating to the role of performance in hydrological prediction and this is where wider science studies have demonstrated the need to move beyond work conducted in either the laboratory or the field to look at numerical prediction.

A wider science that studies the interest in prediction follows from the argument that computer simulation as a practice differs from other scientific approaches because it does not aim to produce new theoretical and general explanations of entities (Knuuttila, 2006) but rather to represent the behaviour that emerges from interactions between those entities (Landström et al., 2013). For instance, most hydrological models are based upon a set of theoretical statements (e.g. Darcy's law, 1856) that are combined together, thus connecting a set of variables that describe the state of the system at any one time. These variables then evolve as defined by their initial values and the theoretical statements but also external forcing. Central to this process is the abstraction of the material world through the choice of particular theoretical statements and their subsequent mathematical description and connection in a hydrological model. Landström et al. (2011a, p. 3) describe this as “... rendering physical processes and events virtual in [hydrological or hydraulic] models ..." Studies of modelling practice have portrayed modelling as: (1) a different kind of laboratory work (e.g. Merz, 2006), reflecting the way in which modellers talk of "numerical experiments"; (2) something that, following Latour, is coproduced with the social order within research communities (e.g. Sundberg, 2009) as modellers develop very particular ways of modelling (e.g. the use of hydrological models based upon similarity of hydrological response); and (3) crucially, something that is performative (Knuuttila, 2006; Peck, 2008; Guillemot, 2010) through its focus upon the extent to which predictions mimic measurements, that is, the model's performance (see also Lane, 2012). Knuuttila (2006) argues that the value of a model depends upon its ability to bring about a prediction that is adequate even if elements of the model are demonstrably wrong. With respect to groundwater models, this has been extensively discussed by Oreskes et al. (e.g. 1994) who talk of the ways in which modellers "force empirical adequacy" in their models, even if this means that they get the "right results" for the "wrong reasons" (Beven, 1989), or even the "wrong results" for the "wrong reasons" if the data that are the object of model forcing are not correct. Models are made to perform.

One of the few attempts to look specifically at the practice of hydrological prediction is contained in Landström et al.'s (2011a, 2013) comparison of consultants and university scientists. They describe how, for the consultants, the predictive modelling was undertaken in a network of formal institutions and regulatory frameworks established for managing flood risk. This network defined the inscription devices (hydrological and hydraulic models, in general) that could be used by the consultants and which guaranteed that their predictions would be comparable to the work of other consultant scientists, that is, the prediction could translate. Lane et al. (2011a) shows that the encoding of this translation in hydrological prediction underpins its primary raison d'être in water resource management: a consistency in evaluation methods that means that geographical locations can be made comparable in space and time, and so evaluated objectively through cost-benefits measures. Porter and Demeritt (2012) have described how flood maps have performed a similar role in the planning process in England and Wales. It is not just the predictive models that become inscribed, it can also be the practices that use those predictions themselves. The attempt to develop a Roughness Advisor (described in Sect. 3.6) as a means of setting Manning's $n$ values was another attempt at restricting how hydraulic predictions should be obtained. In this case, however, Manning's $n$ has proved remarkably resistant to inscription because it is sustained by a network of practice, of consultants, who needed its status as an anti-fact in order to make their models work. Porter and Demeritt (2012) report similar resistance on the part of planners to the use of flood maps to script the planning process. Further, inscription devices may also create a series of challenges or "obstacles" to be overcome by modellers (handling data scarcity, dealing with data error, computational limitations) (Landström et al., 2013). Landström et al. (2013) showed that these challenges are not simply constraints, but also opportunities (Montuori, 2003), the latter seen as a form of improvisation (Landström et al., 2013) necessary to make 
the model perform. Again, the hydrological knowledge that results from this practice cannot be understood if it is divorced from the networks within which it is produced, that is, an assemblage of elements that are material (e.g. conservation of fluid mass, flood defences), technical (e.g. state of knowledge, computational power), regulatory (e.g. defined modelling procedures) and human (e.g. ability to improvise, perception).

The university scientists that were followed confirmed the importance of the networks within which science is practised. As with the consultants, they started with a particular set of "inscription devices", particular hydrological models, ones to which they were accustomed through some years of practice. However, they were working in a network that created a different set of obstacles. They were free to choose their modelling approach, but because they were engaged in participatory hydrological modelling, working with local communities to develop solutions to reduce flood inundation, the obstacles were defined by the solutions that came out of combined academic and community deliberations. The scientists' initial models were incapable of representing the solutions identified and this forced them to create a different kind of model. Landström et al. (2011b) describes this as a dissociation and reattachment, in which the context in which the scientists were working (participatory hydrological modelling) forced them to dissociate from a network that was largely academic and grounded in particular modelling strategies and to reattach themselves to a second network built around a new academic-local community collaboration.

These examples emphasise that prediction in hydrology is concerned with much more than brute forcing of model performance: who the performance is for and how it may be undertaken is important even to the point that "the credibility of a model comes not only from the credentials supplied to it by the governing theory, but also from the antecedently established credentials of the model building techniques developed over an extended tradition of employment ..." (Winsberg, 2003). Still, performance takes on a second and wider meaning because these model-building techniques do not take place freely. Lane et al. (2011a) show how hydrological prediction is critically constrained by a suite of practices that are not characterised simply by the conventions of scientific analysis but are framed by the very management activities that they seek to inform and which determines what can go into the performance. Lane et al. (2011a) consider the example of flood risk management. They show that what drives this activity is not the science of flood inundation but a series of accounting practices that are necessary to define how a hydrological model is to be used (e.g. which simulations are to be considered and what the boundary conditions should be). Returning to the $+20 \%$ rule described above, they showed that certain kinds of hydrological futures were allowed to become dominant over others through a set of codifiers that allowed some types of hydrological non-stationarity to dominate over other, perhaps equally provisional and unstable, elements of the future. For instance, the River Ouse (Sussex) Catchment Flood Management Plan (Environment Agency, 2008) reported a sensitivity analysis of the likely changes in future flood risk arising from climate change (set by applying the $+20 \%$ peak flow rule described above), urban development and land management. Predictions showed that urban development and land management would have very little influence on future flood risk. However, closer inspection of the report reveals the reason for this conclusion (Environment Agency, 2008, p. 106): "Our assessment does not include the impact of any additional building or infrastructure being placed in the floodplain in the future. It is assumed that this will be prevented by appropriate development control, however if it were to occur, the cost of flood damage could increase significantly, depending on the nature of the development (economic and social value) and the depth and frequency of flooding."

The conclusion is not that urban development is unimportant, but rather that regulation is going to prevent it from happening in areas where it might increase flood risk. Lane et al. (2011a) note that the UK's history of constraining urban development in response to established flood risk is extremely poor. In more general terms, this is an example of how hydrological prediction commonly involves an attempt to reduce, through taking assumptions, the ambiguity and uncertainty (Sterling, 2008) in those parts of the system that are indeterminate (see Wynne, 1992) so as to make systems predictable, a process of framing. For instance, the uncertainty of climate change effects is rendered apparently unproblematic through the systematic adoption of a simple $+20 \%$ upscaling rule. Similarly, the ambiguities of things that cannot be known, here notably elements of the social world (e.g. flood development), are reduced through additional codifiers (e.g. that regulation will prevent floodplain development), also a process of framing. The reduction of ambiguity and uncertainty is necessary to make the world predictable. Yet, these kinds of predictions are often the basis of intervention (e.g. the decision to construct a flood defence) and so the success of those interventions becomes directly reliable not only on the reliability of the predictions but the appropriateness of the codifiers that have been required to close or to frame the problem and the associated suite of practices that supports them. Not only must hydrological models mimic the real world, if the interventions in the world that those models sustain are to be effective, the world needs to be made to look like the codifiers and assumptions made by the hydrological models supposed to be representing that world. There is what Baudrillard (1981) calls a "precession of the simulacra", where our world must be made to look like what is assumed in our models. It is one of the dimensions in which the social world is strongly bound to the hydrological world.

The critical point that comes from this argument is that prediction in hydrology, especially in a socio-hydrological framework, needs to be thought through much more carefully because of the power that it has to shape the landscape 
around us. Of course, hydrological prediction exists to help inform decisions that are made about water management. However, if those predictions contain other less clearly stated assumptions, and making those predictions sustainable requires those assumptions to be achieved, then we need a much closer integration of how we live within both hydrological systems and social systems. This is the spirit of the new notion of socio-hydrology (e.g. Sivapalan et al., 2011) which calls for a much more sensitive understanding of how hydrological systems and social systems have evolved together. In the last section of this paper, however, I will go further to argue that prediction in a socio-hydrological world must attend to questions of its social accountability, through its very own practices, if it is to achieve the relevance that it in theory could achieve.

\section{Moving beyond constructivist accounts of hydrology}

As Collins and Evans (2002) argued, the social study of science has contributed much to revealing the nature of science as practised, with some profound implications for how we view the contribution that science and scientists might make to society; but this is far from arguing that science should not be involved in decision-making. Rather, in situations where hydrological science is being practised in public settings, it implies the need to move beyond constructive accounts of hydrology (the second wave), to rethink the nature and position of hydrological expertise as it contributes to societal decision-making (a third wave). My aim in this concluding section is to identify a number of principles as to what such rethinking might involve in a hydrological framework.

\subsection{Working with knowledge controversies}

Hydrological science is inherently controversial (see Lane, 2013). For some elements of hydrological research, this controversy is a necessary part of the development of the discipline, as it forces us to challenge the framings that we bring to our research. For instance, hydrological models can only be shown to be wrong and showing them to be wrong may be what forces those models to develop (Beven, 2006). Yet, when hydrological science is being practised in public (e.g. as part of a water resource or flood risk management strategy), such controversies may become externalised. This is facilitated through a suite of technical (e.g. internet dissemination, social media) and social (expectations regarding freedom of information) changes that not only make scientific knowledge readily open to scrutiny but which increasingly mix facts and opinions in a very public way (Latour, 2011): search engines, tagging, tweeting etc. increasingly determine what it is we think we know. However, it is not simply the case that scientists or certified experts bring facts and publics or non-certified experts bring opinions. The nature of hydrological science as a practice, including its uncertainty, questions the former, and observations in Table 1 question the latter. The controversies become more than just political and inherently bound with knowledge.

As an example, consider the following quote from a local resident in Pickering, North Yorkshire, UK, faced with a controversy about a local flood risk management strategy: "And I suggested $\operatorname{Mr}[X]$ at the $[Y]$ farm, who I knew. We agreed that I would ring him and take the material. He was very interested, and I said I would take the material to him, and leave it with him. He rang me back the following day to say, when was the next meeting of this Environment Agency thing, because he would very much like to go. He was very worried about it. I was able to tell him when the next meeting was, and give him the address of the people and so on. It all went quiet until the next meeting, when he turned up with a sheaf of papers and, I think, about four A4 sheets of paper with figures on, which caused quite a stir, because I don't think the Environment Agency had ever been tackled before - they were quite surprised about it. There was quite a long discussion in that particular meeting. They said they would like to take the paperwork away, and take it back to the firm who were organising this, and see what they said about it. Then we had another meeting in which they said that they certainly weren't prepared to start on the project at Pickering, because there certainly seemed to be some discrepancy there." (Resident of Pickering, North Yorkshire).

The quote above shows how reasoning was slowed down through the creation of a controversy surrounding existing knowledge claims. The first principle then recognises that there is an externalisation of knowledge controversies that follows from the growing capacity of those non-certified experts traditionally excluded from water-related management to both access those controversies traditionally internalised and to bring their own non-certified expertise to bear on them. It argues that when decisions are potentially contentious and the associated knowledge is uncertain, knowledge controversies will develop. Such controversies can unsettle existing framings and, if they are allowed to slow down reasoning, they may provide new framings of problems (Stengers, 2005). We need to work with knowledge controversies rather than trying to manage them or suppress them. As Isobel Stengers puts it: "How can we present a proposal intended not to say what is, or what ought to be, but to provoke thought, a proposal that requires no other verification than the way in which it is able to "slow down" reasoning and create an opportunity to arouse a slightly different awareness of the problems and situations mobilising us?" (2005, p. 994).

Conflict and controversy, wherever it comes from, is an opportunity for us to avoid becoming bound by our own paradigms, to slow down our reasoning, to find perhaps alternative ways forward. If the social and hydrological worlds have co-evolved, letting the social world back in, notably during controversial moments, is a potentially powerful way of innovating hydrological predictions precisely because it 
may force us to be less wedded to our existing hydrological framings. It also represents a fundamental challenge because often institutions see the management and resolution of controversy as a criterion of successful public engagement (Lövbrand et al., 2010). Working with controversies implies seeing them as beneficial things to be harnessed rather than suppressed.

\subsection{Working with and staging events}

Social scientists (e.g. Mustafa, 2002, 2005; Collins, 2009, 2010) who have worked in communities who live with hydrological extremes caution against scientific practices that do not engage with the day-to-day livelihoods of those communities. In such communities, it is often not the hydrological extreme itself that is catastrophic, but the more hidden and continually mutating social processes that determine a community's vulnerability and which make extreme events catastrophic. For most of the time, however connected social and hydrological worlds may have become, hydrological concerns tend to be subordinate to other considerations. This is why events (e.g. a flood) are important in creating the controversial moments when existing problem framings (e.g. that do not recognise the extent to which a social system is also hydrological) may be brought into question. There is an established literature that shows how both events in general and hydrological events (e.g. floods, droughts) in particular can result in major changes in water policy (e.g. Erikson, 1994; Johnson et al., 2005; Lane et al., 2013). Rosario (2007) describes this as a form of "creative destruction" where discourse is no longer capable of explaining the exceptional as normal, in other words reproducing existing expert or policy framings. Rather, out of the destruction, new policy framings may be created.

Working with events, particularly historical events, is a routine practice in hydrological science in both research (e.g. the development of two-dimensional flood inundation mapping has been entirely dependent upon mapped historical events; e.g. Bates, 2004) and practice, not least because most hydrological models have to be forced to reproduce historical events (see Lane et al., 2011a). However, there is a difference between the necessity of assimilating such events into our existing frames of reference, so as to improve those frames (e.g. a mathematical model) and using such events as a means of challenging the very frames themselves. In the dissociation and reattachment surrounding the participatory hydrological modelling described above, Landström et al. (2011b) describes how the university scientists were forced to turn away from an existing hydrological model, and the network of people and models that the model connected them to, as a classical physically based, distributed approach. They went on to develop a completely different model suited to assessing multiple combinations of a large number of distributed interventions (e.g. in-channel debris dams to reconnect the river with its floodplain, small bunds). This shift was at one level related to the pressing flood events that had occurred in the communities with which the scientists were participating; but at a deeper level, the participatory modelling activity was itself an event in the co-evolution of the socio-hydrological system of those communities, albeit one that was staged, in that it itself forced the scientists' dissociation and reattachment, and the eventual reframing of their way of working.

The point here is that we must be careful in seeing "flood events" as somehow different to our own interventions (our "staged events") as hydrological scientists in sociohydrological worlds. Our interventions are both shaped by those socio-hydrological worlds (as the motivation for a socio-hydrology, in Sivapalan et al. $(2011,2012)$, so effectively shows) but also may have profound and not always expected impacts upon that world. Staging events, as experiments situated within communities who live with hydrological problems, may provide an alternative way of both engaging the benefits of community engagement in hydrological prediction and also securing new kinds of framings. The latter may ensure that we, as hydrologists, develop our moral imagination (Coeckelburgh, 2006) so as to be more sensitive to the socio-hydrological world within which we research. However, for this potential to be realised we need to be acutely sensitive to the political and ethical ramifications of what we do, rather than simply seeing these as elements to be excluded so as to secure some kinds of "pure" scientific approach.

\subsection{Being empirical and experimental}

Working with events in general, and the staging of events in particular, can both be seen as a strong commitment to being empirical, where we give primacy to evidence that can be acquired through experience above and beyond theory, or particular frames of enquiry. In this sense, this principle is a comfortable one for hydrology as a field or laboratory science, grounding our work in what we can experience and using this experience to test our speculations, framings etc. as we attempt to move them along Latour and Woolgar's (1979) continuum of facticity and as we attempt to allow certain explanations to stabilise in preference to others (Stengers, 2000). If we continually expose our framings or hypotheses to the test (cf. Beven, 2001), and events staged or otherwise help us to do this, we will escape the problems that arise when particular framings become both stable and dominant. There is a clear parallel here with wider approaches to working with what are sometimes called "wicked problems" (after Rittel and Webber, 1973), ones that at any one point are not completely understood despite progress in managing them needing to be made, such that management has to be "adaptive", especially in the face of uncertainty (Holling, 1978).

But a comment follows. This principle advocates a wider definition of what the empirical might be, namely, as more than just what can be measured. In the way that a sociohydrological world involves more than just hydrology, it also 
implies a widening of what we, as hydrologists, admit into our studies of that world. The socio-hydrological world is replete with instances where what is either difficult or impossible to measure dominates how we make decisions (e.g. the role of heuristics in determining how we live with risk, see for example; Slovic, 2000); and such information requires a much broader definition of what we mean by the empirical. This is particularly important to avoid Baudrillard's (1981) precession of the simulacra, described above, in which the assumptions about human behaviour necessary to make predictions in a socio-hydrological world have to be reproduced in the management of the world around us, so that our predictions remain viable. Such an activity can only lead to the kinds of thought control that Aldous Huxley imagined in a Brave New World (1932), where we have to render human subjects as objective through making them conform to the conditions required for that objectivity (Latour, 1999b). As Huxley's fictional account shows, the only consequence of such a rendering is that human subjects become inherently incapable of being objective, that is, incapable of evaluating their day-to-day lives through any framework other than that which is imposed upon them.

Thus, being empirical in a socio-hydrological world will need a strong commitment to combined social-hydrological investigations that frame the way that prediction is undertaken, rather than leaving consideration of social and economic considerations as concerns to be bolted on to the end of a hydrological study. In the words of Stengers (2000, p. 160): “... It is not a question here of having citizens "vote" ... [e.g. on hydrological futures] ..., but of inventing apparatuses ... [e.g. forms of public participation in hydrological research] ... such that citizens of whom scientific experts speak ... [e.g. in socio-hydrological models or modelling projects] ... can be effectively present, in order to pose questions to which their interest makes them sensible, to demand explanations, to posit conditions, to suggest modalities, in short to proceed in the invention ... [of socio-hydrological predictions]."

Being experimental follows directly from being empirical. The notion of experiment is effectively defined as a soughtfor experience (following Francis Bacon's Novum Organum Scientiarum, published in 1620), that is, empiricism through design. It carries the belief that an idea or notion has to be tested, and that this can be done through experimental proof (Stengers, 2000). Again, this is a comforting notion to a hydrologist, and in a socio-hydrological world, it points to the importance of both events in general, and staged events in particular, as forms of experimental activity. Still, it has a wider implication: in a socio-hydrological world, it is not simply a case of putting hydrologists' notions of the hydrological world or the social world, as "certified experts", to the test, but also those of non-certified experts, recognising that publics may be "no more pusillanimous than the researchers ... no more prisoners of their beliefs than the experts" (Callon, 1999, p. 88). Putting knowledge to the test is about more than simply seeing local people as a source of local knowledge to test what we scientists believe, assumed necessary for hydrologists to make better predictive models. It is about creating forms of participation, experiments, involving both certified and non-certified hydrological experts that allow all hydrological expertise to be put to the test.

\subsection{The co-production of socio-hydrological predictions}

The notion of the staged event or experiment described above challenges the supposed importance that a gap is maintained between the concerns of hydrological science with the hydrological world, typical more generally of traditional models of scientific activity, and those concerns of the social world. Sivapalan et al.'s (2011) notion of socio-hydrology challenges this gap substantively; my account above does so methodologically. The importance of a methodological dimension is threefold. The first is political. As noted above, with a commitment to excluding politics from science, so that scientifically derived knowledge is deemed authoritative, we are actually making a political statement, because we are transferring considerable power to those invested as scientists (Latour, 1999b). In effect, we are denying the existence of two different elements of the framing process (Wesselink and Hoppe, 2011), the "is" that relates to the framing of the problem by knowledge production, and the "ought" that refers to "the norms, values, ideals and interests at stake" (Wesselink and Hoppe, 2011, p. 399). If special status is given to framing the "is", and hence to certain individuals (i.e. scientists), then there is a risk that inadvertently we are also transferring to scientists a right to frame the "ought". That is, in tying to strip values, beliefs, and politics out of science, so as to guarantee its claim to a higher form of knowledge, we are simultaneously transferring to scientists, perhaps inadvertently, substantial power in defining what the considered norms, values, ideals and interests should be.

The second follows in relation to socio-hydrological prediction, and is concerned with democratic accountability. As Aumann (2011) argues, because model predictions relate to a not yet known future, and because those predictions need to make assumptions about more than just the natural world, there is a democratic responsibility to allow those being described by those models to be equally involved in assessing those assumptions made. The third is more practical. Lane (2012) argues that hydrological modelling has evolved a series of practices (e.g. repetition in experiment, experimental control, statistical inference, peer review) as an internal (and partly externalised when published) means of strengthening trust in the knowledge it produces. If practising such science develops the trust that we, as scientists, hold in our own work, then the only means by which others might develop that same trust may be through involvement in the same practices (Yearley, 2005). This is particularly the case given the uncertainty endemic to sociohydrological modelling as discussed above. There is a clear 
rationale for inventing apparati (after Stengers, 2000) that allow us to stage socio-hydrological experiments. Following Callon (2005, p. 312) it: “... [implies] ... the establishment of a concerned group ... [that] ... involves a process of exploration and experimentation that gradually endows that group with the competences it needs to clarify its preoccupations, to demonstrate the existence of those issues and to organise investigations on possible solutions ..."

One way of thinking about such an apparatus is to see the objective of research as being the co-production of knowledge (e.g. Callon, 1999) in which progress is made through apprenticeship to the active creation of knowledge about a problem in a specially created public forum, a special kind of staged experiment. Such a forum may have a number of characteristics. First, it should have a "matter of concern", not necessarily pre-defined, which motivates a sense of controversy and hence a motivation and commitment from both certified and non-certified experts to address that matter of concern. Second, the staging makes the forum "an event" and the event is designed to be experimental in the sense that the forum is experimenting with making an intervention in the evolution of the controversy, through the coproduction of knowledge (Lane, 2013). Third, those implicated in the forum should apprentice themselves to the production of knowledge regarding the matter of concern rather than to what they know or think that they know or desire a priori. Fourth, such a forum should bring into sharp focus the uncertainty and inadequacy of existing accounts regarding the matter of concern, whether those of the certified or the non-certified. Doing that may require help, such as by rendering able those objects that are capable of demonstrating to us what it is we do not know (Latour, 1999b), such as flood risk maps. Fifth, such a forum should be concerned with more than just debate, but active production of socio-hydrological knowledge, or "testimony" (e.g. oral accounts, measurements, photographs, models predictions, reports) that forces us to reappraise what is, precisely, our matter of concern. Sixth, this testimony, including its production, should slow down reasoning so that alternative framings can develop and, in due course, new approaches to sociohydrological prediction might come about.

\subsection{Environmental Competency Groups as an example of co-production}

I have recently been involved in the development of such a forum, called the "Environmental Competency Group" (ECG; Lane et al., 2011b; Whatmore and Landström, 2011b) in two locations in England: Pickering, North Yorkshire, a town on Pickering Beck, a tributary of the Yorkshire Derwent; and Uckfield, East Sussex, in southern England, on the Uck River, a tributary of the Sussex Rye. In both cases, there was a history of flood events, but also little progress towards delivering a flood risk management scheme that was sufficient and acceptable in the eyes of the local community members. The problems were profoundly sociohydrological. For example, in Pickering, the matters of concern were not simply related to managing hydrological risk, but equally about the urban riverscape and its protection, a co-evolved socio-hydrological system.

ECGs were organised in each location for a period of 9- to 12 months. Recruitment to the groups focused upon identifying local members for whom flooding was a matter of personal (and not professional) concern, who would then work with academic members to produce new knowledge in relation to flooding in each locality. Thus, the groups tended to exclude those stakeholders linked to governmental organisations, and they were also not designed to be representative through some kind of artificial sampling. It was recognised that "representation" required an a priori closure of the problem, to define what was to be represented. As the ECGs were not representative, their contribution was not designed to define or to solve a problem, but rather to create new knowledge that might slow down reasoning, allowing the space for new framings of the problem to be created. For instance, in Pickering, advertisements in newspapers, shops and libraries were used to identify possible ECG members. These were then interviewed by a Facilitator to help to identify those for whom flooding was a matter of personal concern and who were willing to sign up to a set of basic principles, including producing rather than just talking about knowledge in collaboration, over a 9-to 12-month period (see Lane et al., 2011b, for more details). The Facilitator organised the meetings and was also responsible for engaging with local members between meetings to support and to address their concerns.

Broadly speaking, initial meetings in both locations were designed to establish the ECGs and their principles, including those described above, but also to overcome a series of prejudices upon the part of both academic and local members. For instance, at the start and in both cases, there was a sense amongst local members that "knowledge" resided in the academic members. To address this, all members were encouraged to bring objects that somehow demonstrated their personal connection to flooding as a matter of concern, such as a piece of damaged carpet, old photographs, a laptop that had been destroyed. The initial meetings were also designed to frame the kind of flooding that the group would look at. Through discussion of both past events as experienced in particular places, experience of other places, knowledge of reports, but also the hydrological knowledge of academic members, the nature of flooding in the two locations was identified, the kinds of analyses required were discussed, and ways forward for testing were considered. This framing was important, as it rapidly tied groups' activities to both predictive modelling as a means of producing new knowledge and the data needed to sustain those models. Local members as well as academics formulated what the models should do and were actively involved in setting them up, using them, and discussing the results. The models became powerful "objects" in challenging what it was that both academic and 
local members thought that they knew about hydrological processes and management in both of the studied locations.

In both cases, at one level, the end result of the ECGs was a product. In Pickering, it was an exhibition attended by over 200 people, along with a report Making Space for People in Flood Risk Management, a direct play on the UK government's Making Space for Water strategy in flood risk management (DEFRA, 2005). The group's work was incorporated into a DEFRA demonstration project Slowing the Flow (http://www.forestry.gov.uk/ fr/INFD-7YML5R), although the DEFRA project emerged separately and in parallel with the ECG work. In Uckfield, the product was more focused on the model itself, and whilst this was not finished at the end of the Uckfield ECG, a Masters student took the modelling forward, applying it in the Uckfield catchment to identify a series of low-level interventions that are now being taken forward in a collaboration amongst the local members and the local Environment Agency. The key element of both of these end results was not that the problem of reducing flood risk in the study catchments was resolved. Rather, each ECG was able to create new knowledge about flood risk that was able to move the controversy on, in different directions, notably towards flood risk reduction that used the wider catchment rather than simply relying upon local flood defences. However, there was a second level of "output". In both cases, this output can be described as a "socio-hydrological public", that is, a grouping of ordinary people, communities and academics, with a new sense of their socio-hydrological knowledge. This output was not a solution to pressing hydrological problems, but rather a public that was capable of making ongoing interventions in the development of socio-hydrological policy in both cases. In this sense, the purpose of these socio-hydrological research projects was neither pure (e.g. the development of new hydrological understanding) nor applied (e.g. the development of new approaches to hydrological prediction) but rather the creation of socio-hydrological publics capable of intervening in ways that slowed down reasoning and, ultimately, created the space for new kinds of hydrological management.

It might be argued that the problem that we considered here had already been framed and that our Environmental Competency Groups were doing little more than expanding the pool of knowledge working within that frame: in what ways did the ECGs genuinely open up the "deliberative space" associated with flooding (Lövbrand et al., 2010)? Indeed, in both of the case studies where we tried out Environmental Competency Groups we could not escape the fact that we were bringing some kind of framing to the problem: we had chosen two sites where flooding was a live and important issue. Nevertheless, through the way we approached the problem, as academics, we were forced to reframe the problem that we had arrived with. As described above, we were forced to break away from our normal networks of practice and invest in and involve ourselves in creating new networks with new framings of the problem. Practically, these new framings meant that we could not use the mathematical models we wanted to, nor could we explore the kinds of landscape interventions that we were most interested in. At one level, the frame remained "flooding"; but at another, the framing had evolved substantially as we had to develop new models and test interventions with which we were not entirely comfortable but which the new network, involving those for whom flooding was a "matter of concern" had defined. This is the sense in which participatory knowledge production can contribute to the democratisation of decision-making even if, on its own, it cannot provide a sufficient account of how decisions are made. In both of the cases we studied, prior to our intervention, the problem had been closed down, framed as beyond all possible solution. Our interventions, very much in the words of Stengers (2005), slowed down the progress of the reasoning that these floods could not be managed. Whilst our knowledge production did not produce solutions, it did provide enough knowledge to reframe flood risk management strategies, where new and unforeseen "solutions" are now being applied. It did this because the new knowledge that was created shook the existing and assembled systems of decision-making (see Lane et al., 2013) in the terms of these systems' own reference, that is, knowledge. In turn, it gave to local members of the Competency Groups a newfound capability, through their knowledge, to influence decision-making processes previously closed to them. This was not because they were not normally consulted, but rather because during normal consultations, local members did not have any meaningful knowledge with which to challenge decision-makers, and the consultants that they employed. The Competency Groups were profoundly anti-technocratic in that, whilst the Competency Groups developed new forms of technical expertise, the right to hold that expertise was not defined by the level of an expert's technical certification. Of course, antitechnocratic does not mean democratic, but there is a debate to be had as to whether the shift in power described here results in processes that are more democratic.

\section{Conclusions}

In 1999, in the millennium issue of the British Journal of Sociology, Bruno Latour wrote “... it might be about time for social and natural scientists to forget what separates them and start looking jointly at those "things" whose hybrid nature has, for many decades now, already unified in practice ..." (Latour, 1999b, p. 116). Socio-hydrological systems, ones associated with the co-evolution of humans and water (Sivapalan et al., 2012), will be "things" that have to be hybrid because their explanation cannot be reduced to their component parts. However, the essence of my argument in this paper is that embracing socio-hydrological systems as a substantive research concern necessarily implies a reformulation of the relationship between us as hydrological scientists, other 
kinds of scientists, notably social scientists, and the world that we seek to study. We cannot avoid our motivation for a socio-hydrological approach coming from the world as we see it; and we must also recognise that the science that we do can itself intervene in that world, the more so when the boundaries of hydrological enquiry are enlarged to include an explicitly social component.

My review of the three broad critiques that sustain the notion that scientific knowledge is constructed appear to be equally relevant to hydrological practice: how we present what we do, including our supposed separation from the objects of our study may not always hold, whatever our intentions may be, as we actively create scientific knowledge through the ways in which we frame what we do; hydrological science does not appear to linearly flow into policy and practice; and those who live with water-related problems may also contain substantial hydrological knowledge. Our sociohydrological world is made through socio-hydrological science in practice, and this includes the practices associated with hydrological prediction. My analysis of one small but important element of hydrological prediction, roughness parameterisation using Manning's $n$, emphasises how effective prediction requires "anti-facts", those parameters that are extremely resistant to quantification through either process relationships or measurements because they are needed to make models perform. Further, I show that hydrological prediction can only proceed when it is framed by social definitions (e.g. as to what return period infrastructure must protect to, and hence the river flow that must be applied to flood inundation models) something that further challenges the notion that scientists study socio-hydrological systems in isolation from those systems.

However, if socio-hydrological practices are also informed by social definitions, socio-hydrological investigations must also understand what it is that shapes those definitions, including their political and ethical content. This requires social science to be undertaken with hydrological science throughout the practice of prediction, and not simply bolted on to the end of hydrological enquiry, as sometimes is the case. The last section of my argument drew upon a series of principles that might be used in these kinds of investigations. These principles include, first, the importance of working with knowledge controversies, especially those increasingly externalised in socio-hydrological enquiry, through new forms of knowledge dissemination (e.g. the internet). Such controversies may provide an opportunity to challenge particular hydrological framings of the world and to innovate in the kinds of predictive models that we use. Second, we need to continue to make use of hydrological events, but also to recognise that when we work in a socio-hydrological world, our activities may themselves constitute an event, one that has the power to transform local communities through the science that we do. Intervening in a socio-hydrological world can never be simply analytical, because that analysis may go on to have transformative effects for the livelihoods of people in those communities studied. Thinking about our interventions as staged events should force us to think through precisely what might result from the work that we do in a broader sense than simply the hydrological science we wish to develop. Third, we need to recognise that working in a socio-hydrological system can help us to be both empirical and experimental in ways that prevent our lock-in to particular frames of enquiry. The notion of experiment, where knowledge is put to the test, is a reminder that all of us, whether certified or not, learn most when we discover that what we thought we knew no longer holds, that we are wrong. Finally, we need to develop and to explore ways in which we can co-produce socio-hydrological knowledge through working in the socio-hydrological systems that interest us. Social scientists have developed and tried out a wealth of ideas for this kind of investigation. Thus, my primary conclusion from reading Sivapalan et al. $(2011,2012)$, is that doing prediction in a socio-hydrological world is going to require some very different kinds of hydrological practices as we as hydrological scientists learn to work closely with social scientists, those who best know how to work with and in the social world.

Acknowledgements. This paper is the culmination of my personal involvement in various social-hydrological worlds over the last $13 \mathrm{yr}$. The Rural Economy and Land Use programme funded a project concerned with knowledge controversies in flood risk management (RES-227-250-018), and this project, notably through working with Catharina Landström, Sarah Whatmore and Neil Ward, is where I have been able to develop these ideas. Kate Bradbrook provided helpful and critical comments on an earlier draft of the manuscript and this version of the manuscript benefited immensely from the constructive comments of Editor Veena Srinivasan and Reviewers Liz Stevens and Anna Wesselink.

Edited by: V. Srinivasan

\section{References}

Aumann, C. A.: Constructing model credibility in the context of policy appraisal, Environ. Model. Softw., 26, 258-265, 2011.

Austin, Z., Alcock, R. E., Christley, R. M., Haygarth, P. M., Heathwaite, A. L., Latham, S. M., Mort, M., Oliver, D. M., Pickup, R., Wastling, J. M., and Wynne, B.: Policy, practice and decision making for zoonotic disease management: Water and Cryptosporidium, Environ. Int., 40, 70-78, 2012.

Bacon, F.: Novum Organum Scientificum, Venetiis, Typis G. Giradi, London, 1620.

Barnes, H. H.: Roughness Characteristics of Natural Channels, US Geological Survey, Water Supply Paper 1849, US Government, Washington, 213 pp., 1967.

Bates, P. D.: Remote sensing and flood inundation modelling, Hydrol. Process., 18, 2593-2597, 2004.

Baudrillard, J.: Simulacres et simulation, Editions Galilée, Paris, 233 pp., 1981. 
Beck, S.: Moving beyond the linear model of expertise? IPCC and the test of adaptation, Reg. Environ. Change, 11, 297-306, 2011.

Bertrand-Krajewski, J.-L. and Manning, R.: In the Short Historical Dictionary on Urban Hydrology and Drainage, http://jlbkpro.free.fr/shduhdfromatoz/manning.pdf (last access: 15 April 2010), 2006.

Beven, K. J.: Changing ideas in hydrology: the case of physically based models, J. Hydrol., 105, 157-172, 1989.

Beven, K. J.: On hypothesis testing in hydrology, Hydrol. Process., 15, 1655-1657, 2001.

Beven, K. J.: On undermining the science?, Hydrol. Process., 20, 3141-3146, 2006.

Beven, K. J.: Environmental modelling: an uncertain future?, Taylor and Francis, London, 2008.

Bickerstaff, K. and Simmons, P.: The right tool for the job? Modeling, spatial relationships, and styles of scientific practice in the UK foot and mouth crisis, Environ. Plan. D, 22, 393-412, 2004.

Bijker, E., Hughes, T., and Pinch, T. (Eds.): The Social Construction of Technological Systems: New Directions in the Sociology and History of Technology, Cambridge, MIT Press, Massachusetts, 411 pp., 1987.

Bijker, W. E.: Sustainable Policy? A Public Debate About Nature Development in the Netherlands, Hist. Technol., 20, 371-391, 2004.

Bijker, W. E.: Dikes and dams, thick with politics, ISIS, 98, 109123, 2007a.

Bijker, W. E.: American and Dutch coastal engineering: differences in risk conception and differences in technological culture, Social Stud. Sci., 37, 143-151, 2007 b.

Brownlie, W. R.: Flow depth in sand-bed channels, J. Hydraul. Eng., 109, 959-990, 1983.

Brysse, K., Oreskes, N., O’Reilly, J., and Oppenheimer, M.: Climate change prediction: Erring on the side of least drama?, Global Environ. Change, 23, 327-337, 2013.

Callon, M.: The role of lay people in the production and dissemination of scientific knowledge, Sci. Technol. Human Val., 4, 81-94, 1999.

Callon, M., 2005. Disabled people of the world unite!, in: Making Things Public, edited by: Latour, B. and Weibel, P., MIT Press, Cambridge, MA, 308-313, 2005.

Chanson, H.: The Hydraulics of Open Channel Flow: An Introduction, Butterworth-Heinemann, Oxford, 512 pp., 1999.

Chow, V. T.: Open-channel Hydraulics, McGraw-Hill, New York, 680 pp., 1959.

Coeckelbergh, M.: Regulation or responsibility? Autonomy, moral imagination, and engineering, Sci. Technol. Human Val., 31, 237-260, 2006.

Collins, H. M. and Evans, R.: The third wave of science studies: studies of expertise and experience, Social Stud. Sci., 32, 235296, 2002

Collins, T. W.: The production of unequal risk in hazardscapes: An explanatory frame applied to disaster at the US-Mexico border, Geoforum, 40, 589-601, 2009.

Collins, T. W.: Marginalization, facilitation, and the production of unequal risk: The 2006 Paso del Norte Floods, Antipode, 42, 258-288, 2010.

Cowan, W. L.: Estimating hydraulic roughness coefficients, Agricult. Eng., 37, 473-475, 1956.
Darcy, H.: Les Fontaines Publiques de la Ville de Dijon, Dalmont, Paris, 1856.

Darcy, H. and Bazin, H. E.: Recherches hydrauliques, première partie, Recherches experimentales sur l'écoulement de l'eau dans les canaux decouverts, Imprimérie nationale, Paris, 501 pp., 1865.

Darier, E., Shackley, S. and Wynne, B.: Towards a 'folk integrated assessment' of climate change?, Int. J. Environ. Poll., 11, 351372, 1999.

DEFRA: Taking forward a new Government strategy for flood and coastal erosion risk management in England: first Government response to the autumn 2004 Making space for water consultation exercise, DEFRA, London, 47 pp., 2005.

Demeritt, D.: The Construction of Global Warming and the Politics of Science, Ann. Assoc. Am. Geogr., 91, 307-337, 2001.

Demeritt, D.: Science studies, climate change and the prospects for constructivist critique, Econ. Soc., 35, 453-479, 2006.

Dooge, J. C. I.: The Manning formula in context, in: Channel flow resistance - Centennial of Manning's formula, edited by: Yen, B. C., Water Resources Publications, Littleton, Colorado, 136-185, 1992.

Eden, S. and Tunstall, S.: Ecological versus social restoration? How urban river restoration challenges but also fails to challenge the science-policy nexus in the United Kingdom, Environ. Plan. C, 24, 661-680, 2006.

Environment Agency: River Ouse catchment flood management plan, Environment Agency, Worthing, UK, 2008.

Erikson, K. T.: A new species of trouble: The human experience of modern disasters, Norton, New York, 263 pp., 1994.

Ferguson, R. I.: Flow resistance equations for gravel-and boulder-bed streams, Water Resour. Res., 43, W05427, doi:10.1029/2006WR005422, 2007.

Fleck, L.: Genesis and Development of a Scientific Fact, Published in English in 1981 by the University of Chicago Press, Chicago, 203 pp., 1935.

French, R. H.: Open-Channel Hydraulics, McGraw-Hill, New York, 739 pp., 1985.

Ganguillet, E. and Kutter, W. R.: A general Formula for the Uniform Flow of Water in Rivers and other Channels, Translated to English, 1889, edited by: Hering, R. and Trautwine, J. C., John Wiley and Sons, New York, 1869.

Garde, R. J. and Raju, K. G. R.: Mechanics of sediment transportation and alluvial stream problems, Wiley Eastern, New Delhi, 483 pp., 1977.

Gooding, D.: Mapping experiment as a learning process: how the first electromagnetic motor was invented, Sci. Technol. Human Val., 15, 165-201, 1990.

Govindaraju, R. and Erikson, L.: Modelling of overland flow contamination due to heavy metals in shallow soil horizons, Proceedings of the 10th Annual Conference on Hazardous Waste Research, Kansas State University. Kansas, 287-300, 1995.

Guillemot, H.: Connections between simulations and observation in climate computer modeling. Scientist's practices and "bottomup epistemology" lessons, Stud. Hist. Philos. Modern Phys., 41, 242-252, 1995.

Hering, R. and Trautwine, J. C.: A general Formula for the Uniform Flow of Water in Rivers and other Channels, John Wiley and Sons, New York, 1889.

Hicks, D. M. and Mason, P. D.: Roughness Characteristics of New Zealand Rivers, NIWA, Wellington, New Zealand, 1991. 
Hicks, D. M. and Mason, P. D.: Roughness characteristics of New Zealand Rivers, NIWA, New Zealand, 336 pp., 1998.

Holling, C. S. (Ed.): Adaptive Environmental Assessment and Management, Wiley, Chichester 1978.

Horton, R. E.: Some better Kutter's formula coefficients, Eng. News Rec., 75, 373-374, 1916.

HR Wallingford Ltd.: Scoping Study for Reducing Uncertainty in River Flood Conveyance, R \& D Technical Report to DEFRA/Environment Agency, available at: http://www. river-conveyance.net/ces/documents/ScopingReport2001.pdf (last access: 17 June 2013), 2001.

HR Wallingford, 2002: Reducing uncertainty in river flood conveyance, Phase 2, Inception Report, Defra/Environment Agency Flood and Coastal Defence R\&D programme, Project W5A-057, Environment Agency, Bristol, 39 pp. plus figures and Appendices, http://www.river-conveyance.net/ces/ documents/Inception\%20ReportWeb\%20version.pdf (last access: 17 June 2013), 2002.

HR Wallingford: Reducing uncertainty in river flood conveyance, Roughness Review, Defra/Environment Agency Flood and Coastal Defence R \& D programme, Project W5A-057, Environment Agency, Bristol, 209 pp., http://www.river-conveyance.net/ ces/documents/RoughnessReviewFinal_July07.pdf (last access: 17 June 2013), 2003.

HR Wallingford: Reducing uncertainty in river flood conveyance, Phase 2, Conveyance Manual, Defra /Environment Agency Flood and Coastal Defence R\&D programme, Project W5A-057/PR/1, Environment Agency, Bristol, 94 pp., available at: http://www.river-conveyance.net/ces/documents/CES_ UserGuide.pdf (last access: 17 June 2013), 2004.

Huxley, A.: A brave new world, Chatto and Windus, London, 288 pp., 1932.

Irwin, A.: Sociology and the Environment, Polity Press, Cambridge, 224 pp., 2001.

Jasanoff, S.: A New Climate for Society, Theor. Cult. Soc., 27, 233 253,2010

Johnson, C. L., Tunstall, S. M., and Penning-Rowsell, E. C.: Floods as catalysts for policy change: Historical lessons from England and Wales, Int. J. Water Resour. Develop., 21, 561-575, 2005.

Johnson, M. S.: Public participation and perceptions of watershed modelling, Soc. Nat. Resour., 22, 79-87, 2009.

Keulegan, G. H.: Laws of turbulent flow in open channels, J. Res. Natl. Bureau Stand., 21, 707-741, 1938.

King, H. W.: Handbook of hydraulics for the solution of hydraulic problems, McGraw-Hill, New York, 424 pp., 1918.

Knuuttila, T.: From Representation to Production: Parsers and Parsing in Language Technology, in: Simulation: Pragmatic Construction of Reality, edited by: Lenhard, J., Kuppers, G., and Shinn, T., Springer, Dordrecht, 41-55, 2006.

Kropp, C.: River landscaping in second modernity, in: Making things public, Atmospheres of democracy, edited by: Latour, B. and Weibel, P., MIT Press, Massachussetts, 486-491, 2005.

Kuhn, T. S.: The Structure of Scientific Revolutions, University of Chicago Press, Chicago, 1962.

Lahsen, M.: Seductive simulations? Uncertainty distribution around climate models, Soc. Stud. Sci., 35, 895-922, 2005.

Landström, C., Whatmore, S. J., and Lane, S. N.: Virtual engineering: Computer simulation modelling for flood risk management in England, Science Stud., 24, 3-22, 2011a.
Landstrom, C., Whatmore, S. J., Lane, S. N., Odoni, N., Ward, N., and Bradley, S.: Coproducing flood risk knowledge: redistributing expertise in critical 'participatory modelling', Environ. Plan. A, 43, 1617-1633, 2011b.

Landström, C., Whatmore, S. J., and Lane, S. N.: Learning through computer model improvisations, Sci. Technol. Human Val., 38, 678-700, 2013.

Lane, S. N.: Roughness - time for a re-evaluation, Earth Surf. Proc. Land., 30, 251-253, 2005.

Lane, S. N.: Making mathematical models perform in geographical space(s), Chapter 17 in: Handbook of Geographical Knowledge, edited by: Agnew, J. and Livingstone, D., Sage, London, 228245, 2012.

Lane, S. N.: Working with controversies in hydrology and hydraulic science, in: Hydrosystèmes continentaux et territoires européens confrontés aux différentes lois sur l'eau, edited by: ArnaudFassetta, G., Masson, E., and Reynard, E., Verlag, Munich, 171$182,2013$.

Lane, S. N., Landstrom, C., and Whatmore, S. J.: Imagining flood futures: risk assessment and management in practice, Philos. T. Roy. Soc. A, 369, 1784-1806, 2011a.

Lane, S. N., Odoni, N., Landström, C., Whatmore, S. J., Ward, N., and Bradley, S.: Doing flood risk science differently: an experiment in radical scientific method, T. Inst. British Geogr., 36, 15$36,2011 b$.

Lane, S. N., November, V., Landström, C., and Whatmore, S. J.: Explaining rapid transitions in the practice of flood risk management, Ann. Assoc. Am. Geogr., 103, 330-342, 2013.

Latour, B.: Pandora's hope: essays on the reality of science studies, Harvard University Press, Cambridge Massachusetts, 336 pp., 1999a.

Latour, B.: When things strike back - a possible contribution of 'science studies' to the social sciences, British J. Sociol., 51, 105123, $1999 \mathrm{~b}$.

Latour, B. and Woolgar, S.: Laboratory Life: The Social Construction of Scientific Facts, Sage, Beverly Hills, 1979.

Latour, B.: Waiting for Gaia. Comparing the common world through arts and politics, Lecture to the French Institute, London, November 2011, text available at: www.bruno-latour.fr (last access: 15 April 2013), 2011.

Lebossé, A.: Estimation of the Manning Strickler roughness coefficient in Saint-Venant equations, in: Channel flow resistance Centennial of Manning's formula, edited by: Yen, B. C., Water Resource Publications, Littleton, Colorado, 1992.

Leopold, L. B. and Wolman, M. G.: River channel patterns: meandering, braided and straight, US Geological Survey, Professional Paper, 282-B, US Government, Washington, 85 pp., 1957.

Leopold, L. B., Bagnold, R. A., Wolman, M. G., and Brush Jr., L. M.: Flow Resistance in Sinuous or Irregular Channels, US Geological Survey Professional Paper 282-D, US Geological Survey, 34 pp., 1960.

Liken, G. E.: The role of science in decision making: does evidencebased science drive environmental policy?, Front. Ecol. Environ., 8, 1-9, 2010.

Limerinos, J. T.: Determination of the Manning coefficient from measured bed roughness in natural channels, Water Supply Paper 1898-B, US Geological Survey, 47 pp., 1970. 
Lövbrand, E., Pielke Jr., R., and Beck, S.: A democracy paradox in studies of science and technology, Sci. Technol. Human Val., 23, 4-15, 2010.

Lynch, M.: Technical work and critical inquiry: investigations in a scientific laboratory, Soc. Stud. Sci., 12, 499-533, 1982.

Manning, R.: On the flow of water in open channels and pipes, $\mathrm{T}$. Inst. Civil Eng. Ireland, 20, 161-207, 1891.

Merz, M.: Locating the Dry Lab on the Lab Map, in: Simulation: Pragmatic Construction of Reality, edited by: Lenhard, J., Kuppers, G., and Shinn, T., Springer, Dordrecht, 155-172, 2006.

Montuori, A.: The complexity of improvisation and the improvisation of complexity, Social science, art, and creativity, Human Relations, 56, 237-255, 2003.

Mustafa, D.: To each according to his power? Access to irrigation water and vulnerability to flood hazard in Pakistan, Environ. Plan. D, 20, 737-752, 2002.

Mustafa, D.: The production of an urban hazardscape in Pakistan: Modernity, vulnerability, and the range of choice, Ann. Assoc. Am. Geogr., 95, 566-586, 2005.

Nikuradse, J.: Stromungsgesetze in rauhen Rohrne (Laws of flow in rough pipes), Ver. deutscher Ingenieure, Forschungsheft, Berlin, No. 361, Translated by the National Advisory Committee for Aeronautics, and published as Technical Memorandum 1292 in 1950, http://ntrs.nasa.gov/archive/ nasa/casi.ntrs.nasa.gov/19930093938_1993093938.pdf (last access: 16 April 2010), 1933.

Oreskes, N.: Science and public policy: what's proof got to do with it?, Environ. Sci. Policy, 7, 369-383, 2004.

Oreskes, N. and Conway, E. M.: Merchants of Doubt: How a handful of Scientists observed the truth on issues from tobacco smoke to global warming, Bloomsbury Press, New York, 2010.

Oreskes, N., Shrader-Frechette, K., and Belitz, K.: Verification, Validation, and Confirmation of Numerical Models in the Earth Sciences, Science, 263, 641-646, 1994.

Pal, A.: A study of open channel and pipe flow equations in the light of Manning's formula, Irrigation and Power, October 1965, Central Board of Irrigation and Power, New Delhi, 521-524, 1965.

Peck, S. L.: The hermeneutics of ecological simulation, Biol. Philos., 23, 383-402, 2008.

Petts, J. and Brooks, C.: Expert conceptualisations of the role of lay knowledge in environmental decision-making: challenges for deliberative democracy, Environ. Plan. A, 38, 1045-1059, 2006.

Pielke, R. A.: The honest broker: making sense of science in policy and politics, Cambridge University Press, Cambridge, 2007.

Porter, J. and Demeritt, D.: Flood risk management, mapping and planning: the institutional politics of decision-support in England, Environ. Plan. A, 44, 2359-2378, 2012.

Prandtl, L.: Uber die ausgebildeter turbulenz (On fully developed turbulence), International Congress in Applied Mechanics, Zurich, 62-74, 1926.

Richards, K. S.: Rivers: Form and Process of Alluvial Channels, Methuen, London, 358 pp., 1982.

Rittel, H. W. J. and Webber, M. W.: Dilemmas in a General Theory of Planning, Policy Sci., 4, 155-169, 1973.

Rosario, K.: The culture of calamity: Disaster and the making of modern America, University of Chicago Press, Chicago, 320 pp., 2007.
Rosenkrantz, B. G.: Reflections: Genesis and Development of a Scientific Fact by Ludwik Fleck, edited by: Trenn, T. J., Merton, R. K., and Bradley, F., Isis, 72, 96-99, 1981.

Royal Society: Science and the public interest, The Royal Society, London, 2006.

Scobey, F. C.: The flow of water in irrigation channels, Bulletin 194, US Department of Agriculture, 1915.

Shackley, S., Risbey, J., Stone, P., and Wynne, B.: Adjusting to policy expectations in climate change modeling - An interdisciplinary study of flux adjustments in coupled atmosphere-ocean general circulation models. Climatic Change, 43, 413-454, 1999.

Simons, D. B. and Şentürk, F., Resistance to flow, in: Sediment Transport Technology, edited by: Simons, D. B. and Şentürk, F., Water Resource Publications, Fort Collins, 1976.

Sivapalan, S., Thompson, S., Harman, C., Reed, P., Montanari, A., Schumer, R., Blöschl, G. McGlynn, B., Wagener, T., Reinfelder, Y. F., Marshall, L., Istanbulluoglu, E., Troch, P., Shaman, J., Niyogi, D., Band, L., Savenije, H., Chhatre, A., and Wilson, J.: Predictions under Change (PUC): Water, Earth and Biota in the Anthropocene, Draft 1: April 18, 2011, www.iahs.info/ .../PUCresearch_agendaDraft1_April18\%20(2).docx** (last access: 27 June 2013), 2011.

Sivapalan, M., Savenije, H. H. G., and Blöschl, G.: Sociohydrology: A new science of people and water, Hydrol. Process. 26, 1270-1276, 2012.

Slovic, P.: The perception of risk, Earthscan Publications, London, 473 pp., 2000.

Smith, H. M., Wall, G., and Blackstock, K. L.: The role of mapbased environmental information in supporting integration between river basin planning and spatial planning, Environ. Sci. Policy, 30, 81-89, 2012.

Stengers, I.: The invention of modern science, in: Theory Out of Bounds, Volume 19, University of Minnesota Press, Minneapolis, 185 pp., 2000.

Stengers, I.: The cosmopolitical proposal, in: Making Things Public, edited by: Latour B. and Weibel, P., MIT Press, Cambridge, MA, 994-1003, 2005.

Stephens, E. M., Bates, P. D., Freer, J. E., and Mason, D. C.: The impact of uncertainty in satellite data on the assessment of flood inundation models, J. Hydrol., 414, 162-173, 2012.

Stewart, J.: Facts as commodities?, Radical Sci. J., 12, 129-140, 1982.

Stirling, A.: "Opening up" and "closing down": power, participation, and pluralism in the social appraisal of technology, Sci. Technol. Human Val., 33, 262-294, 2008.

Strickler, A.: Beiträge zur Frage der Geschwindigkeitsformel und der Rauhigkeitszahlen fur Ströme, Kanaäle und Geschlossene Leitungen, Berne, 1923.

Sturgis, P. and Allum, N.: Science in society: re-evaluating the deficit model of public attitudes, Public Understand. Sci., 13, 5574, 2002.

Subramanya, K.: Flow in Open Channels, Volume 1, Tata McGrawHill, New York, 224 pp., 1982.

Sundberg, M.: The Everyday World of Simulation Modeling: The Development of Parameterizations in Meteorology, Sci. Technol. Human Val., 34, 162-181, 2009.

Tilley, N.: The Logic of Laboratory Life, Sociology, 15, 59-67, 1981. 
Trudgill, A. and Richards, K.: Environmental science and policy: Generalizations and context sensitivity, T. Inst. British Geogr., 22, 5-12, 1997.

von Karman, T.: Mechanische Aehnlichkeit und turbulenz (Mechanical similarity and turbulence), Volume 1, International Congress in Applied Mechanics, Stockholm, 85-92, 1930.

von Mises, R.: Elemente der technischen Hydrodynamik, Teubner, Leipzig, 1914.

Weber, E. P., Memon, A., and Painter, B.: Science, Society, and Water Resources in New Zealand: Recognizing and Overcoming a Societal Impasse, J. Environm. Policy Plan., 13, 49-69, 2011.

Wesselink, A. and Hoppe, R.: If post-normal science is the solution, what is the problem?: The politics of activist environmental science, Sci. Technol. Human Val., 36, 389-412, 2011.

Wesselink, A. J., Vriend, H. J. D., Barneveld, H. J., Krol, M. S., and Bijker, W. E.: Hydrology and hydraulics expertise in participatory processes for climate change adaptation in the Dutch Meuse Water, Water Sci. Technol., 60, 583-595, 2009.

Whatmore, S. J. and Landström, C.: Manning's N: putting roughness to work, Chapter 4 in: How Well Do Facts Travel? The Dissemination of Reliable Knowledge, edited by: Howlett, P. and Morgan, M. S., Cambridge University Press, Cambridge, 111135, 2011 a.

Whatmore, S. J. and Landström, C.: Flood-apprentices: An exercise in making things public, Econ. Soc., 40, 1-29, 2011 b.

Willcocks, W. and Holt, R.: Elementary hydraulics, National Printing Office, Cairo, 74 pp., 1899.
Wiman, B. L. B.: Implications of environmental complexity for science and policy - contributions from systems-theory, Global Environ. Change, 1, 235-247, 1991.

Winsberg, E.: Simulated Experiments: Methodology for a Virtual World, Philos. Sci., 70, 105-125, 2003.

Wittfogel, K.: Oriental despotism: a comparative study of total power, Random House, New York, 1957.

Wolman, M. G.: The natural channel of Brandywine Creek, Pennsylvania, US Geological Survey Professional Paper 271, US Geological Survey, 56 pp., 1955.

Wynne, B.: Uncertainty and environmental learning - reconceiving science and policy in the preventive paradigm, Global Environ. Change, 2, 111-127, 1992.

Wynne, B.: Strange weather again: climate science as political art, Theor. Cult. Soc., 27, 289-305, 2010.

Yearley, S.: Making sense of science, Sage, London, 205 pp., 2005.

Yu, D. and Lane, S. N.: Urban fluvial flood modelling using a twodimensional diffusion wave treatment: 1 Mesh resolution effects, Hydrol. Process., 20, 1541-1565, 2006.

Zhang, G. P. and Savenije, H. H. G.: Rainfall-runoff modelling in a catchment with a complex groundwater flow system: application of the Representative Elementary Watershed (REW) approach, Hydrol. Earth Syst. Sci., 9, 243-261, doi::10.5194/hess-9-2432005, 2005. 